Pablo Seguel, Prácticas de poder de las clases subalternas en el desarrollo del poder popular en Chile, 1967-1973 Political subjectivization practices in the development of the popular power in Chile, 1967-1973, Revista Izquierdas, 27, abril 2016, ISSN 0718-5049, pp. 161 - 199

\title{
Prácticas de poder de las clases subalternas en el desarrollo del poder popular en Chile, 1967-1973*
}

\section{Political subjectivization practices in the development of the popular power in Chile, 1967-1973}

\author{
Pablo Seguel Gutiérrez ${ }^{* *}$
}

\footnotetext{
*Esta reflexión se fue desarrollando a partir de diversas presentaciones sobre la relación entre movimientos sociales, sistema de partidos y poder popular en el Seminario a 40 años del golpe militar. Usos y abusos de la memoria realizada por las Escuelas e institutos de historia de Chile (centro Cultural Gabriel Mistral), el congreso Construcción y recuperación de la memoria histórica: reflexión a 40 años del golpe militar (Universidad de Chile) y la IV Jornada de historia de las Izquierdas (Universidad Santiago de Chile). El presente trabajo constituye el resultado de las investigaciones que antecedieron a la elaboración y presentación de dichas ponencias.

** Chileno. Licenciatura en Historia, egresado de sociología, Universidad de Chile. Proyecto Bicentenario para el estudio de los movimientos sociales: memoria social y poder. Contacto: bseguelg@gmail.com
} 


\section{Resumen:}

En el presente artículo cuestionamos el consenso político que desde finales de la década de 1970 diagnosticó las fallas del proceso de politización de las clases subalternas chilenas que llevaron al quiebre de la democracia, el fracaso del proyecto de la Unidad Popular y que culminó en la dictadura militar. A través del análisis de las prácticas de poder de las clases subalternas chilenas damos cuenta de las profundas transformaciones en la cultura política, que puso en entredicho el Estado de Compromiso y que se expresó en torno al debate sobre la noción y alcance del poder popular en el proceso de la vía chilena al socialismo.

Palabras clave: poder popular, clases subalternas, Unidad Popular, Estado de Compromiso, subjetivación política, prácticas.

Recibido: 12 agosto 2015

Aceptado: 23 diciembre 2015

\begin{abstract}
:
In this paper, we will question the political consensus that, from the end of the decade of 1970, diagnosed the flaws of the process of politicization of chilean subaltern classes, that led to the break-down of democracy, the failure of the Unidad Popular project and that culminated in military dictatorship. By means of the analysis of the subaltern chilean classes' practices of power, we account for the profound transformations in the political culture of the time, that called the Commitment's Satate into question and that expressed itself on the debate and reach of Popular Power in the process of the chilean route to socialism.
\end{abstract}

Keywords: popular power, subaltern class, Unidad Popular, Commitment's State, political subjectivization, practices.

\section{La práctica investigativa y sus usos políticos.}

El estudio de la formación de la línea estratégica de la izquierda en Chile se ha desarrollado principalmente en torno al análisis de discurso de la dirigencias partidarias y sus intelectuales orgánicos. A partir de ello, las lecturas efectuadas sobre la racionalidad política y los errores del proceso de la vía chilena al socialismo han generado un tipo de análisis que desacopla la relación orgánica entre partidos, intelectuales y los movimientos sociales como campos de producción, circulación y usos de sentidos prácticos. Este sesgo de observación ha determinado un tipo análisis que toma como sujeto del proceso a los intelectuales y a los partidos políticos como campos cerrados de producción de sentido, generando una lectura de los procesos de politización sobre la consideración de un modelo de racionalidad política formal. Desde ese marco la mayoría de las investigaciones efectuaron un diagnóstico sobre el funcionamiento del sistema de partidos y el régimen democrático que, al mismo tiempo que criticó elementos centrales del diseño político de la izquierda del momento, posibilitó un uso político de la memoria del proceso de politización llevado adelante por las clases subalternas chilenas. 
Pablo Seguel, Prácticas de poder de las clases subalternas en el desarrollo del poder popular en Chile, 1967-1973 Political subjectivization practices in the development of the popular power in Chile, 1967-1973, Revista Izquierdas, 27, abril 2016, ISSN 0718-5049, pp. 161 - 199

Uno de los focos centrales del análisis se constituyó en la relación entre sistema de partidos, movimientos sociales y Estado. Las conclusiones a las que llegó el grueso del campo cultural de la izquierda durante los ochenta tomaron una importancia central. La reflexión generada en ese contexto tuvo una fuerte carga de contingencia, posibilitando leer el fracaso de la Unidad Popular en sentido de futuro, fundamentando, así, el grueso de la estrategia transitológica que se puso en marcha desde mediado de los ochenta. La clave política para el éxito de la transición se leyó en la manera en cómo se identificó el fracaso de la Unidad Popular.

Este modo de comprender al campo cultural de la izquierda, nos permitirá atender a las articulaciones sociales, de tal modo de relacionar los procesos de circulación, producción y usos de las prácticas y discursos investigativos con un determinado contexto sociopolítico. Nuestro objetivo es criticar el uso político de la memoria de movilización social y subjetivación política efectuado por los intelectuales orgánicos de la transición, develando los fundamentos que las amparan, tales como un modelo de racionalidad política formal, el uso nociones abstractas de democracia, de Estado de derecho, de régimen de partido. Análisis que los llevaron a la consideración del fracaso de la Unidad Popular por efecto de la rigidización del sistema de partidos, por la imposibilidad de estructurar un centro político estable, que hubiese permitido la generación de alianzas amplias, flexibles y moderadas que se sobrepusieran a la política de los resquicios legales. En suma, un problema de racionalidad política que exigía la morigeración de los proyectos políticos, un realismo político para la mantención de alianzas amplias y flexibles que hubiesen asegurado un marco institucional para la resolución negociada de los conflictos sociales.

Con ello buscamos criticar lo que en la literatura historiográfica referida al estudio de la Unidad Popular, constituye un consenso político: la disputa de dos líneas estratégicas y sus dificultades en establecer una dirección única, dado por la disociación, en una de ellas, entre "los mapas cognitivos con los que se leía la realidad" y los "hechos de la realidad misma", generando un "empate catastrófico" y una situación de inmovilismo político que concluyó en el golpe de Estado.

Reconociendo que esta situación de parálisis a nivel político se generó, nuestro análisis critica al diagnóstico que está de trasfondo y que se fue instalando en el campo cultural de la izquierda chilena, desde finales de 1970 y que es el núcleo discursivo de la memoria hegemónica que refieren a la experiencia de politización de las clases subalternas en Chile. Núcleo que al construir una lectura de la experiencia de politización como una excepcionalidad, desplaza la responsabilidad del Golpe de Estado al proceso de politización de las clases subalternas y legitima, indirectamente, la intervención excepcional de la dictadura, como un proceso necesario, de re-fundación del orden republicano, sobre el cual era ineludible consolidar una nueva democracia, moderna, consociativa y de reconocimiento para el desarrollo del conjunto de la nación. ${ }^{2}$

\footnotetext{
${ }^{1}$ Tomás Moulian, "La vía chilena al socialismo: itinerario de la crisis de los discursos estratégicos de la Unidad Popular", Cuando hicimos Historia. La experiencia de la Unidad Popular, Santiago, LOM ediciones, 2005, p. 37, 40. Tomás Moulian, Democracia y Socialismo, Santiago, FLACSO, 1983, p. 89.

2 Ángel Flisbish, La política como compromiso democrático, Santiago, FLACSO, 1987.
} 
Pablo Seguel, Prácticas de poder de las clases subalternas en el desarrollo del poder popular en Chile, 1967-1973 Political subjectivization practices in the development of the popular power in Chile, 1967-1973, Revista Izquierdas, 27, abril 2016, ISSN 0718-5049, pp. 161 - 199

Diagnóstico que, al presentar a ambos proceso como excepcionales tiene un doble efecto a nivel político de presentarnos a las prácticas de politización de las clases subalternas como un exceso, como toda la politización posible a la que pudo llegar el movimiento popular en el marco de una sociedad capitalista, estructuralmente heterogénea y periférica. Al mismo tiempo, permite señalarnos el recurso de la fuerza como una operación de excepción de derecho, que intervino para corregir esta situación exceso en la práctica de la democracia por parte de las clases subalternas.

Sin buscar agotar la crítica de este enfoque en construcción, ${ }^{3}$ generaré en esta oportunidad algunas claves de lectura que nos permitan contribuir al ejercicio señalado desde el campo de la historiografía. ${ }^{4}$ Para ello tomaré en cuenta las transformaciones de las prácticas de poder que hemos evidenciado en el desarrollo de la experiencia de poder de las clases subalternas chilenas. Prácticas y experiencias que anticipaban una nueva cultura política en el campo cultural de la izquierda chilena, que rompió las formas clásicas de mediación de lo social y lo político desarrolladas desde el Frente Popular en adelante, cuya característica principal fue el carácter prefigurativo ${ }^{5}$ de la construcción del socialismo y que intuitivamente comenzó a nombrarse como poder popular.

Al colocar el énfasis en las prácticas criticamos la investigación historiográfica basada en la cosificación de experiencias, es decir, en la objetivación y universalización de las mismas, a través de los cuáles son evaluados las experiencias históricas y los procesos de formación de agentes colectivos. Por ello, ponemos el énfasis en las prácticas sociales discretas e históricamente inscritas en un contexto. Como señala Paul Veyne, "heurísticamente, es mejor partir del detalle de las prácticas, de lo que se hacía y se decía, y hacer el esfuerzo intelectual de explicitar con ello el discurso; es más fecundo (...) que arrancar de una idea general y muy conocida, pues nos arriesgamos entonces a atenernos a esta idea, sin advertir las diferencias últimas y decisivas que la reducirán a nada"6

Siguiendo una línea historiográfica crítica para el estudio de los procesos de politización, ${ }^{7}$ entendemos por práctica lo que los hombres dicen y hacen cuando hablan y

\footnotetext{
${ }^{3}$ En gran medida estas reflexiones las hemos ido desarrollando en conjunto con el Dr. Miguel Urrutia Fernández, académico del departamento de Sociología. Miguel Urrutia y Pablo Seguel, "El aporte de las ciencias humanas a las pervivencias del golpe de Estado. Cuarenta y más años para una ruptura democrática en Chile". Sociedad Hoy 25, Concepción, $2^{\circ}$ sem. 2013, pp. 97-143.

${ }^{4}$ para una revisión teórica de este debate: Pablo Seguel, "Politización subalterna, democracia y excepción en Chile: entre la acumulación flexible y la Gobernabilidad Democrática (1976-1989)", inédito.

${ }^{5}$ Miguel Mazzeo, Introducción al poder popular. El sueño de una cosa, Santiago: Tiempo Robado Editoras, 2014.

${ }^{6}$ Paul Veyne, Foucault: pensamiento y vida. Barcelona, Paidós, 2009, p. 19.

${ }^{7}$ Olga Echeverría y Lucía Lionetti, "La Historia Política en su complejidad: los aportes de la historia cultural y la historia intelectual", ponencia presentada a la V Jornadas Nacionales de Historia Moderna y Contemporánea. Paul Veyne, Cómo se escribe la historia. Madrid, Alianza Editorial, 1984. Michel Foucault, Seguridad, territorio, población. Buenos Aires, Fondo de Cultura Económico, 2011. Michel Foucault, El nacimiento de la biopolítica, Buenos Aires, Fondo de Cultura Económica, 2012. Santiago Castro-Gómez, Historia de la gubernamentalidad. Razón de Estado, liberalismo y neoliberalismo en Michel Foucault, Bogotá, Siglo del Hombre editores, 2010.
} 
Pablo Seguel, Prácticas de poder de las clases subalternas en el desarrollo del poder popular en Chile, 1967-1973 Political subjectivization practices in the development of the popular power in Chile, 1967-1973, Revista Izquierdas, 27, abril 2016, ISSN 0718-5049, pp. 161 - 199

actúan en el espacio social. ${ }^{8}$ Prácticas en el sentido de los haceres concretos de determinados agentes individuales y colectivos, formado por acciones y discursos.

$\mathrm{Al}$ analizar las prácticas como discursos, no se pone el énfasis en el contenido del habla, en su coherencia lógica, sino que en su funcionamiento, en los efectos de realidad que produce. Es decir, es describir sus efectos y contra efectos en lo real y no presuponer nada más, no suponer que hay un objetivo, un objeto o una causa material. Desde esta perspectiva, la racionalidad de una práctica política no radica en el contenido del discurso, en su coherencia lógica, en lo que dice o no dice, sino en los efectos que configura en los conjuntos de los actores, instituciones y organizaciones. En otras palabras, la racionalidad es el modo de funcionamiento práctico configurado a partir de los agentes, las instituciones y las organizaciones. ${ }^{9}$

Como hemos señalado en otros trabajos, "Las prácticas (discursivas y no discursivas) son acontecimientos, por tanto, emergen en determinados momentos de la historia, quedando inscritas en un entramado de relaciones sociales, de posiciones, disposiciones y tomas de posición en un entramado de relaciones sociales, de posiciones, disposiciones y tomas de posición en un modelo de Red". ${ }^{10}$ En específico atenderemos sobre todo a las prácticas de poder expresadas en movilización y subjetivación política.

Por prácticas de movilización social se entiende a las diversas maneras en que los agentes individuales y colectivos de la época irrumpieron o modificaron el campo político. Por su parte, por subjetivación política nos referimos al proceso consistente en cuestionar las funciones y retribuciones resultantes de una determinada configuración del poder social. Por ello, al estudiar las prácticas de poder de las clases subalternas comprendemos a las diversas formas de movilización y subjetivación política que reconfiguraron el campo político de la época, generando rupturas y readecuaciones en las expresiones de poder de decisión y acción de los agentes.

Nuestro objetivo es cuestionar los relatos de la politización de las clases subalternas que se expresaron con fuerza en el proceso de la vía chilena al socialismo. Experiencias históricas que en la década de 1980 fueron leídos bajo la perspectiva de la transición política en marcha y que tuvo como resultado la construcción de un discurso de la politización popular que delimitó el campo de lo posible, a la vez que estableció las sanciones de no-político, anómico o irracional a los repertorios de acción, movilización y subjetivación de las clases subalternas chilenas. Es decir, el uso político de la práctica investigativa constituyó el discurso hegemónico desde el cual, hasta la fecha, se ha legitimado la transición política e invisibilizado los proyectos antagonistas desarrollados,

\footnotetext{
${ }^{8}$ Entendemos por espacio social "conjunto de posiciones distintas y coexistentes, externas unas de otras, definidas en relación unas de otras, por su proximidad mutua y relaciones de orden". Desde esta perspectiva, "sus propiedades por lo tanto son relacionales, por cuanto quedan estructuradas sólo a través de relaciones contingentes con otras prácticas”. Pierre Bourdie, Razones prácticas. Barcelona, Anagrama, 1994, p. 17. Para la noción de prácticas, véase: Castro-Gómez, op. cit. p. 28.

${ }^{9}$ La racionalidad refiere al funcionamiento histórico de las prácticas. Castro-Gómez, op. cit. , p.

${ }^{10}$ Pablo Seguel, op. cit.
} 
por lo que en ese momento histórico, comprendió al amplio espectro de actores y organizaciones de los pobres de la ciudad y el campo.

\section{Crítica a la práctica investigativa y sus usos políticos.}

Nuestra inquietud de investigación ha tomado la atención de varias generaciones de investigadores, que han generado diferentes marcos de análisis para la explicación del fracaso político de la Unidad Popular (UP) con usos políticos respectivos. Las explicaciones en general han oscilado entre aquellas que identifican en el factor externo el elemento crucial, dado por la intervención norteamericana, conjugada a la sedición de la alta oficialidad del ejército apoyada por la derecha "rupturista" y las clases dominantes, y entre las que colocan el foco del análisis en los propios límites y errores de la Unidad Popular.

En ese último grupo de investigaciones, sin desconocer el efecto de la injerencia externa, se han deslizado cuatro grandes agrupamientos que organizan distintos marcos interpretativos que buscan explicar el problema al que nos referimos. El primer grupo de investigadores pone el énfasis en que en la polarización del conflicto político y en la rigidización del sistema de partidos se contiene el grueso de la explicación del fracaso de la dirección política de la UP, tomando como premisa la constitución del Estado de Compromiso y la configuración del Régimen de Partidos.

Partiendo de la explicación de Arturo Valenzuela, que señala que la extrema polarización que dio lugar al quiebre de la democracia se debió al "fracaso en estructurar un centro político viable en una sociedad altamente polarizada con fuertes tendencias centrífugas". 11 Siguiendo con Alejandro Foxley, que coloca el énfasis en la "existencia de proyectos globales cerrados y excluyentes, incapaces de dialogar y llegar acuerdos". ${ }^{12}$ Hasta la explicación de Eugenio Tironi y Javier Martínez, que tomando el marco del Régimen de Partidos enfatiza el error en la racionalidad de la elite política del sistema de partidos. Así, señalan que la "incapacidad de la clase política chilena, que presa de atavismos ideológicos no supo administrar racionalmente las consecuencias del proceso de modernización e integración social que ella misma impulsó". ${ }^{13}$ En suma, un problema de racionalidad política que exigía la morigeración de los proyectos políticos, un realismo para la mantención de alianzas amplias y flexibles que hubiesen asegurado un marco institucional para la resolución negociada de los conflictos sociales.

Otro grupo de investigadores, tomando el grueso de esta argumentación, ha enfatizado en las limitantes internas del propio bloque socialista la tensión central, caracterizada por una oposición entre polos con líneas políticas estratégicas en tensión. En ese sentido, los primeros trabajos de Tomás Moulian identificaron la crisis del régimen político en la imposibilidad de establecer alianzas entre la izquierda y el centro, que hubiesen permitido

\footnotetext{
${ }^{11}$ Arturo Valenzuela, El quiebre de la democracia en Chile, Santiago, FLACSO, 1978, p. 27.

${ }^{12}$ Alejandro Foxley, Para una democracia estable: economía y política, Aconcagua, CIEPLAN, 1985.

${ }^{13}$ Javier Martínez y Eugenio Tironi, Las clases sociales en Chile, Santiago, SUR, 1985 p.54.
} 
Pablo Seguel, Prácticas de poder de las clases subalternas en el desarrollo del poder popular en Chile, 1967-1973 Political subjectivization practices in the development of the popular power in Chile, 1967-1973, Revista Izquierdas, 27, abril 2016, ISSN 0718-5049, pp. 161 - 199

la construcción de un "bloque por los cambios" como una alternativa a la política de los resquicios legales que terminó quebrando la forma tradicional de la política de compromiso. Enfatizando, además, en base a los estudios de Giovanni Sartori, como crítica al trabajo de Arturo Valenzuela, que un centro estable por sí solo no otorgó la estabilidad al sistema democrático chileno. ${ }^{14}$

Sobre esta tesis de fondo, para Luis Corvalán Márquez, ${ }^{15}$ la explicación de la polarización de los conflictos políticos que permitió el derrumbe institucional, fue el resultado de la combinación de: la gran habilidad táctica del sector rupturista de la oposición, el considerable peso que, a su vez, las fuerzas rupturistas alcanzaron en la izquierda y la inexistencia -en un marco de un sistema de partidos de pluralismo polarizado- de un centro pragmático, capaz de dar a través de un acuerdo moderado con el gobierno, una contribución significativa a la despolarización del escenario político".

En este mismo grupo de investigadores, el reciente trabajo de Isabel Jara, enfatiza el carácter ideologizado del centro político como factor explicativo de un sistema político configurado a partir de la noción de los tres tercios políticos que introdujo en la década de 1950 Aníbal Pinto. ${ }^{16}$ Así, para Jara "entre los años 1964-65 se puso fin a la fase de reacomodo y transición. A partir de entonces se afianzó un sistema de partidos que se caracterizó por tener un centro ideologizado con una tendencia permanente a la polarización. La elección de 1970 reflejó aún la permanencia de los tres tercios irreductibles, pero se produjo un proceso de extrema radicalización"17

Finalmente, siguiendo este marco de análisis, Marcelo Casals intenta dar cuenta de la tensión entre el polo rupturista y el sistémico, poniendo el énfasis en el proceso de formación de las líneas estratégicas de los principales partidos (PS-PC-MIR), identificando en la "disociación" entre una "retórica rupturista" y "práctica sistémica", el principal factor de explicación de la crisis en el marco de proyectos globales excluyentes. ${ }^{18}$

Estos dos grupos de investigadores, constituyen un conjunto de trabajos que toma como objeto del análisis la racionalidad política de las organizaciones partidarias sobre una noción sistémica y normativa del Régimen de Paridos y de la Democracia. ${ }^{19}$ Tesis que

\footnotetext{
${ }^{14}$ Tomás Moulian, Fracturas. De Pedro Aguirre Cerda a Salvador Allende (1938-1973). Chile, Santiago, LOM, 2006. Tomás Moulian, "La vía chilena al socialismo: itinerario de la crisis de los discursos estratégicos de la Unidad Popular", en: Julio Pinto, (coo.), Cuando hicimos Historia. La experiencia de la Unidad Popular, Chile, Santiago, LOM, 2005, p. 37, 40. Tomás Moulian, op. cit., p. 89. Moulian, Tomas, Contradicciones del desarrollo político chileno, Santiago, LOM, 2010, p. 51.

${ }^{15}$ Luis Corvalán, Los partidos políticos y el golpe del 11 de septiembre. Contribución al estudio del contexto histórico, Santiago, Ediciones Universidad Bolivariana.

${ }^{16}$ Aníbal Pinto, Chile, un caso de desarrollo frustrado, Santiago, Editorial Universitaria, 1962.

${ }^{17}$ Isabel Jara, La crisis del sistema democrático: las elecciones presidenciales y los proyectos políticos exlcuyentes. Chile, 1958-1970, Santiago, Editorial Universitaria, 2014, p. 34.

${ }^{18}$ Marcelo Casals, El alba de una revolución. La izquierda y el proceso de construcción estratégica de la "vía chilena al socialismo". 1956-1970, Santiago, LOM, 2011. La noción de proyectos globales fue introducida por Mario Góngora. Véase: Mario Góngora, Ensayo histórico sobre la noción de Estado en Chile en los siglos XIX y XX, Santiago, Editorial Universitaria, 1998, pp. 280-305.

${ }^{19}$ Para un desarrollo mayor de estas nociones en la Ciencia Política, véase: Eduardo Villarreal Cantú y Hugo Martínez González (Coord.), (Pre) Textos para el análisis político, México DF, Flacso-México, 2010.
} 
Pablo Seguel, Prácticas de poder de las clases subalternas en el desarrollo del poder popular en Chile, 1967-1973 Political subjectivization practices in the development of the popular power in Chile, 1967-1973, Revista Izquierdas, 27, abril 2016, ISSN 0718-5049, pp. 161 - 199

llevan irremediablemente a afirmar la necesidad de articulaciones políticas cercanas a la idea de la "matriz sociopolítica" de Manuel Antonio Garretón ${ }^{20}$ y que, como bien ha criticado Aldo Mascareño, ${ }^{21}$ establecen un marco de análisis universalizante que desplaza el centro del análisis desde las prácticas concretas y sucesivas de politización, hacia conceptos abstractos que rigen el funcionamiento normal de una sociedad. Así, por vía intelectual, se normaliza la acción política y el sistema social en un marco de análisis cuyo límite está sobre el funcionamiento actual de la democracia y que nos lleva, si es que lo aceptamos sin reparos, a erigirlo como el parámetro desde el cual imputar las prácticas políticas antagonistas de las clases subalternas, reduciendo la subjetivación política a la mera acción partidaria y la racionalidad política a la mera racionalización instrumental.

En ese marco de análisis, la racionalidad política sólo será comprendida como la identificación por parte de un actor de la lógica operante en las instituciones sociales y el campo de interés que estas configuran, evacuando dos momentos fundamentales de la política y de la construcción política: el momento de la ruptura de lo real como orden de cosas dadas (la emergencia del antagonismo como acontecimiento que rompe con el orden sucesivo de las cosas) y el momento de institucionalización de lo nuevo (el momento de la institución soberana del orden social). ${ }^{22} \mathrm{Su}$ funcionalidad política fue y es, por tanto, la de generar un marco reflexivo para la izquierda, que la llevase/lleva a aceptar la tesis de la transición consociativa y la necesidad de generar alianzas amplias, flexibles y moderadas, desechando los componentes diferenciadores y antagonistas de la lucha política, para la preservación de espacios concertados para la resolución negociada de los intereses.

Otro grupo de investigadores, que han puesto el centro en el problema de la historicidad de la sociedad y la subjetividad política, han identificado esta tensión, pero han desplazado el análisis desde un problema de dirección política, hacia un problema en las formas de mediación política ${ }^{23}$. Así, este sector, señala en el caso de Peter Winn, una tensión entre las formas de mediación políticas - por arriba y expresada por los partidos del bloque socialista- con las formas de participación desde abajo, expresadas en el protagonismo llevados adelante por las propias dinámicas internas de los trabajadores. ${ }^{24}$ Por su parte, Mario Garcés y Pedro Milos desarrollan esta problemática como "mayores grados de

\footnotetext{
${ }^{20}$ Manuel Antonio Garretón, El proceso político chileno, Santiago, FLACSO, 1983.

${ }^{21}$ Aldo Mascareño, "Acción y estructura en américa Latina. De la matriz sociopolítica a la diferenciación funcional”, En: Persona y sociedad, , vol. XXIII, no. 2, Santiago, Universidad Alberto Hurtado 2009, pp. 6589.

${ }^{22}$ Al respecto, véase: Massimo Modonosi, Subalternidad, antagonismo, autonomía. Marxismo y subjetivación política. Buenos Aires, CLACSO, 2010.

${ }^{23}$ Entendemos como formas de mediación política a las diversas formas de organización que adoptan los agentes sociales para la expresión del antagonismo político. Va desde las formas organizacionales sociales, hasta las formas organizaciones partidarias y estatales. Para la revisión de la noción de organización, véase: Iván Valenzuela, "Modernidad, Teoría Social y Organización: reflexiones sobre antiguos desencuentros y nuevos encuentros", Revista Ciencias Sociales, 12, 2002 pp. 93-107.

${ }^{24}$ Peter Winn, Los tejedores de la revolución, Chile, Santiago: LOM, 2004, p. 21-22.
} 
Pablo Seguel, Prácticas de poder de las clases subalternas en el desarrollo del poder popular en Chile, 1967-1973 Political subjectivization practices in the development of the popular power in Chile, 1967-1973, Revista Izquierdas, 27, abril 2016, ISSN 0718-5049, pp. 161 - 199

autonomización e instrumentalización" en distintas coyunturas del sistema. ${ }^{25}$ En el caso más radical, Gabriel Salazar, que si bien critica la utilización de universales como parámetro para el análisis de las prácticas de politización, ${ }^{26}$ aborda este problema como un efecto de la tendencia intrínseca de la representación institucional y de toda forma de mediación política, ${ }^{27}$ desechando junto con ella la necesidad de las articulaciones sociales y políticas.

El problema de este enfoque es que en la crítica hacia la acción política restringida al parámetro de lo institucionalizado, supone que en el establecimiento de un afuera a lo institucionalizado se posibilita la transformación social, identificando -por defecto- a las articulaciones partidarias como espacios de neutralización de la acción antagonista. Cuando por el contrario, el problema de las articulaciones remite a un problema de oportunidades políticas contextuales. El uso político de estas tesis es, por tanto, funcional a la despolitización de las fuerzas populares, porque desecha la necesidad de las articulaciones, reduciendo el campo táctico de las oportunidades políticas y tendiendo, en el plano estratégico, hacia la atomizar de los esfuerzos de organización y politización, dificultándoles la tarea de articularse globalmente. El nivel teórico es un esfuerzo crítico que se queda sólo en el momento de la imputación del orden constituido y que no se plantea una salida realista la reorganización de un proyecto político.

Finalmente, el último sector, asumiendo el resguardo frente a estas generalizaciones, nos plantea el problema de la mediación como un problema de racionalidad política en el marco de las características propias de la formación social chilena. Es decir, como problema estrictamente político desplegado en el marco del análisis socioeconómico. El primero de este tipo de trabajo, desde una lectura estructuralista, lo constituyen los textos de Ruy Mauro Marini que, basándose en las características propias del sistema de dominación en Chile y el pacto de dominación construido desde la década de 1930, identifica las limitantes políticas en la amplitud de las alianzas a construir, como en el comportamiento político de las capas medias y las estrategia llevada adelante por la izquierda, como las principales trabas del proceso de la UP. ${ }^{28}$ Análisis similar al desplegado por Juan Carlos Marín, abocado a la situación específica del agro. ${ }^{29}$ La crítica a este enfoque, no radica en la racionalidad del análisis, sino a la sobre-determinación socioeconómica que se genera a la acción política, siendo la subjetivación el resultado de la

\footnotetext{
${ }^{25}$ Mario Garcés, "Lo político y lo social”, en Revista Punto Final, no. 599, 2 de septiembre del 2005. Milos, Pedro y Garcés, Mario, Cuadernos de historia popular: serie Historia del movimiento obrero, Santiago, CETRAL/CEAL, no1, 1983.

${ }^{26}$ Gabriel Salazar, La violencia política popular en las grandes alamedas, Santiago, LOM, 2006, pp. $27-66$.

27 Gabriel Salazar, Movimientos sociales en Chile. Trayectoria histórica y proyección política, Santiago, Chile, Uqbar editores, 2006, pp. 17-37

${ }^{28}$ Ruy Marini, ¿Transición o Revolución?, 1973; Dos estrategias en el proceso chileno, 1974; Economía Política de un golpe militar", 1974; La pequeña burguesía y el problema del poder, 1976. [recopilación personal de los textos. Sin edición]. Para un abordaje del fundamento teórico del análisis, véase: Ruy Mauro Marini, Subdesenvolvimento e revolução, Florianópolis, Editora Insular, 2013.

29 Juan Carlos Marín, El ocaso de una ilusión.1967-1973, Buenos Aires, Picaso/INEDH/Colectivo Ediciones, 2007.
} 
Pablo Seguel, Prácticas de poder de las clases subalternas en el desarrollo del poder popular en Chile, 1967-1973 Political subjectivization practices in the development of the popular power in Chile, 1967-1973, Revista Izquierdas, 27, abril 2016, ISSN 0718-5049, pp. 161 - 199

adecuación de la racionalidad de los actores al diagnóstico político presentado por los intelectuales orgánicos, en el binomio conciencia /falsa conciencia propio del modelo de acción político leninista. ${ }^{30}$

Otro grupo de trabajos dentro de este enfoque, desarrollados a partir del problema específico del poder popular, articulan una explicación que toma los elementos de dirección política, del contenido de la formación social, como del dinamismo de la base social de la UP al momento de dar cuenta del problema de politización y la subjetivación política. Así el trabajo de Franck Gaudichaud da cuenta de las tensiones expresadas en la izquierda en Chile y cómo estas cruzan la problemática del poder popular. ${ }^{31}$ Sin embargo, tanto ese trabajo como los de Sandra Castillo, Renzo Henríquez, Cristóbal Bize y Miguel Silva, ${ }^{32}$ suponen la generación de una tensión irreductible entre la forma Estado y el poder y popular, que personalmente considero que se origina no en las formas puras de relación social (forma estado, forma partido, forma poder), sino en el caso chileno específicamente en los vacíos de la formulación estratégica de la vía chilena al socialismo. ${ }^{33}$

Un trabajo que complementa el desarrollo de la problemática planteada por Hugo Cancino, lo constituye el trabajo de Juan Carlos Gómez Leyton y la crítica al uso transitológico de la lectura del fracaso de la Unidad Popular, que permitió identificar en el ocaso de la democracia en Chile una clave para la transformación futura. En ese sentido, la principal crítica esgrimida del autor hacia los primeros dos grupos de investigadores es la de "centrar el análisis en el funcionamiento del régimen político y no en los conflictos que afectaban la estructura de poder de la formación social chilena". ${ }^{34}$

Finalmente, una referencia central corresponde al trabajo de Hugo Cancino, para quien "el triunfo de la Unidad Popular creó condiciones propicias para el desarrollo de un proceso de democratización del poder desde las bases, es decir, del Poder Popular". ${ }^{35}$ En este

\footnotetext{
${ }^{30}$ Tomás Moulian, "El marxismo en Chile: utilización y producción”, En: Contradicciones del desarrollo político chileno, Chile, Santiago, LOM, pp. 87-94.

${ }^{31}$ Franck Gaudichaud, "El gobierno de Salvador Allende y su lucha por el "poder popular" (1970-1973), Poder Popular y Cordones Industriales, Santiago, LOM, 2006, pp. 13-54.

${ }^{32}$ Sandra Castillo, Cordones Industriales. Nuevas Formas de Sociabilidad Obrera y Organización Política Popular (Chile, 1970.1973). Concepción, Escaparate Ediciones, 2010. Miguel Silva, Los Cordones Industriales y el Socialismo desde Abajo, Santiago, autoedición, 2013. Renzo Henríquez, El Poder del Campo. Los campesinos de Maipú durante el gobierno de Allende, Santiago, Londres 38, 2014. Renzo Henríquez, Industria Perlak "Dirigida y Controlada por los Trabajadores". Desalienación obrera en los tiempos de la Unidad Popular, 1970-1973”, Revista www.izquierdas.cl, Santiago, número 20, septiembre 2014. Cristóbal Bize, "Historia y memoria. Hacia una experiencia de poder popular: los trabajadores de la madera en la cordillera de Valdivia. (Neltume, 1970-1971). Memorias, historia y Derechos Humanos. Santiago, Universidad de Chile, 2012, pp.15-36.

${ }^{33}$ Bryan Seguel y Miguel Urrutia, "Prácticas de poder popular y ruptura democrática. Chile, 1965-2014", En: Mazzeo, Miguel, Introducción al poder popular. Chile, Santiago, Tiempo Robado Editoras, 2014, pp. 1136.

${ }^{34}$ Juan Carlos Gómez Leyton, "Democracia versus propiedad privada. Los orígenes político-jurídicos de la dictadura militar chilena", En: Caetaneo, Gerardo (comp.), Sujetos sociales y nuevas formas de protesta en la historia recuente de América Latina, Buenos Aires: CLACSO, 2006, pp. 171-212.

${ }^{35}$ Cancino, Hugo, Chile. La problemática del Poder Popular en el Proceso de la Vía Chilena al Socialismo, Dinamarca: Aarhus University Press. 1988, pp. 15-16.
} 
trabajo el autor da cuenta de cómo el desarrollo del debate y la formulación del poder popular en el contexto histórico-estructural de la vía chilena al socialismo, evidenció una alternativa política que supuso desafíos importantes al proyecto socialista llevado adelante por los partidos de la Unidad Popular. Por este motivo, el autor da cuenta cómo la noción de poder popular se expresaba un "proceso de dinamización de la red de organizaciones sociales de base pre-existentes a la constitución de la UP, como sindicatos, juntas de vecinos y otras asociaciones populares, las que debían ampliar su radio de acción y participación, pero dentro del sistema institucional en el que la vía chilena al socialismo se inscribía". ${ }^{36}$ Por ello, al entrar en crisis las formas de mediación entre lo social y lo políticas, las diversas expresiones de organización y acción en la base social generaron serias dificultades a la conducción política de proceso.

Este trabajo siguiendo estas rutas de análisis, toma como punto de inicio la estructuración del Estado de Compromiso, su sistema de alianza y el tipo de pacto de dominación, para comprender la profundidad de las transformaciones generadas por las prácticas de poder de las clases subalternas en el sistema político como una articulación ampliada. ${ }^{37}$ En específico analizaremos las prácticas discursivas de los dirigentes políticos, intelectuales y sindicales a lo largo del desarrollo de la coyuntura de crisis de la Unidad Popular y del Estado de Compromiso. Enfatizando sobre todo, la subjetivación política de las prácticas discursivas, es decir, los efectos en los actores a partir de la evaluación del cambio en las correlaciones de fuerza de agentes en juego en el proceso político.

Nuestro trabajo parte de la premisa de que no hay que ir a buscar la racionalidad de los agentes políticos a la luz de las ideas de régimen político y de democracia en abstracto, sino que, tenemos que dar cuenta de las articulaciones entre partido y sociedad, organización y agente, en términos contingentes y sucesivos. Es decir entendidas, no como formas preconcebidas a las cuales evaluamos según los parámetros ideales de democracia y partido, sino que en las articulaciones concretas, en las prácticas que van modificando la racionalidad política de los agentes en contextos determinados (situaciones), desarrollándose como producto de los juegos de fuerzas entre los actores en el marco de una formación cultural, que se constituyen de manera razonada pero no necesariamente racionales.

Atender a un esquema de análisis de la acción política partiendo de este sentido práctico de la disputa en el marco de los sistema de hegemonía, que contemple una dimensión de la fuerza y otra del consenso, ${ }^{38}$ precisamente nos permite dar cuenta del sistema de

\footnotetext{
${ }^{36}$ Cancino, Hugo. op. cit., p. 129.

${ }^{37}$ Este análisis lo presentamos en otro trabajo, por lo que no profundizaremos en este aspecto. Bryan Seguel, "La discusión política del Poder Popular en la crisis del Estado Capitalista de Compromiso de Clases. Chile, 1967-1973", en: Construcción y Recuperación de la Memoria Histórica. Reflexiones a 40 años del Golpe Militar”, Santiago, Universidad de Chile, pp. 77-94

${ }^{38}$ La asimilación socialdemócrata del concepto de hegemonía en Antonio Gramsci como la pura dimensión del reconocimiento, posibilitó una relectura política de la democracia que permitió que la renovación socialista en Chile tuviese un marco de análisis que le permitiera identificar en las prácticas de antagonismo como aspectos negativos en la construcción de gobernabilidad democrática. Sin embargo en Gramsci, el
} 
mediaciones entre lo social y lo político, que se fue construyendo en Chile desde la conformación del Estado de Compromiso y que permitió la configuración de una racionalidad política determinada. Pero sobre todo, nos permite comprender que los sistemas de hegemonía remiten a relaciones móviles de actores sociopolíticos en un campo de intereses ampliados, en el que las posiciones ocupadas por las clases subalternas en relación a las clases dominantes en un determinado campo, remiten a prácticas concretas situadas espacial y temporalmente en distintos escenarios, que suponen la conformación de subjetividades políticas que van evaluando sus posibilidades de triunfo en contextos específicos en los que se generan determinadas oportunidades de acción: es decir estrategias de acción razonadas, adecuadas a un determinado campo de acción. La racionalidad política, por tanto, remite a sujetos concretos que en el juego de previsión y proyección de medios para la consecución de objetivos políticos, toman en consideración sus recursos disponibles y el estado de sus fuerzas propias en relación a la de los enemigos. Proceso de desarrollo reflexivo, que junto con el de racionalización, va internamente relacionado al desarrollo de una experiencia de subjetivación en la que se van conformando tanto los marcos normativos como los medios para la evaluación de fines. La politización no remite sólo al cálculo instrumental de fines, sino que también a una evaluación a fines ético-morales, constituyendo un amplio abanico de fines que guían el proceso reflexivo, forjado en una experiencia común, desarrollada en la práctica y ratificada parcialmente en la acción.

El drama histórico de la Unidad Popular fue que los objetivos políticos quedaron formulados en un marco normativo que extraía la legitimidad de la acción en las instituciones del Estado que decía combatir, pese a asentarse discursivamente en la movilización de las clases subalternas que eran consideras como generadoras de soberanía. Sobre ese vacío no teorizado y sin una referencia clara a los espacios de acción, se generó una revolución de prácticas y espacios de antagonismo, que rompieron los espacios tradicionales de mediación política (la multigremial, el sindicalismo y los partidos políticos) y generaron una subjetivación política que, desarrollándose en estas formas, superó las mediación político-partidarios clásicos en las instituciones del sistema político, ampliando la política a la territorialidad de la fábrica, del fundo, de la comuna. En otras palabras, a la generación de un poder subalterno más allá de la teoría de la dualidad del poder que suponen como forma del poder popular algunos intelectuales y más acá de los vacíos de "la vía chilena al socialismo", y cuya racionalidad no se desarrolló al plano de plantearse los problemas del socialismo como problemas de articulaciones de "arriba" y "abajo", puesto que no existió la generación de un espacio de soberanía común que guiara la racionalidad de la contienda desde una dirección colectiva.

Esto no quiere decir que el golpe de estado estaba inscrito en las características del conflicto político de los actores sociales en Chile y que la derecha necesariamente adoptaría una posición golpista, análisis que replicaría la tesis de la excepcionalidad de la

concepto de Hegemonía contempla la dimensión del consentimiento y la del antagonismo. Al respecto, véase nuestro Trabajo. Urrutia y Seguel, op. cit., pp. 125-132. 
politización popular y de la intervención militar desde la proposición de una inevitabilidad histórica. $^{39}$ Por el contario, implicaba comprender que los vacíos en la formulación estratégica de la "vía chilena al socialismo", que se planteaba la construcción de un Estado Popular "desde arriba y desde adentro" (como se verá en el programa de la Unidad Popular y en la estrategia de copamiento sucesivo del Estado desarrollado desde finales de 1930), permitió la activación de diversos espacios de subjetivación política, que pusieron en acción prácticas de politización que rompieron los espacios y formas de la democracia burguesa, agotando la estrategia de copamiento sucesivo de las instituciones del Estado que llevaron adelante el Partido Socialista y el Partido Comunista. Situación ante la cual la Unidad Popular no supo articularse de manera correcta, pasando desde el intento de conformación de un Partido Federado de la Unidad Popular, que diese cabida a los partidos $\mathrm{y}$ estas expresiones, a un rechazo a ultranza y, final y tardíamente, a un reconocimiento sobre el cual apoyar la iniciativa del ejecutivo.

Es sobre este vacío estratégico que se desarrolló la práctica de politización del poder popular de las clases subalternas chilenas: 1) sobre el rol y protagonismo de los actores sociales movilizados y en la subjetivación política que se fue generando desde su experiencia movilización y antagonismo; 2) y en la necesidad de generar un poder orgánico que incidiendo en el aparato estatal, no se redujera al mero copamiento burocrático del mismo.

\section{La Unidad Popular: prácticas de movilización social y subjetivación política en el debate del poder popular.}

El gobierno de la Unidad Popular representó una radicalización del pacto de modernización desarrollista en el marco del ECC bajo orientación hegemónica de los partidos de trabajadores, tomando partido por el trabajo, la socialización del poder, en contra de la propiedad de los medios de producción y la centralización política. ${ }^{40} \mathrm{Su}$ diseño estratégico se basó en la conquista gradual y pacífica del poder político, sin ruptura brusca con el orden burgués, acompañada de la liquidación de las bases de la dominación imperialista, latifundista y monopólica, a través de medidas planteadas en la perspectiva de construcción al socialismo. ${ }^{41}$ Electoralmente se basó en la ascendente movilización y radicalización social presenciada desde 1967, sumando a nuevos actores sociales como mujeres y jóvenes, ${ }^{42}$ y desde un comienzo experimentó la contradicción de ser un gobierno que representaba los intereses de los trabajadores, pero que tenía su fuente de "legitimidad" en las instituciones del ECC. Esta característica estará en el centro de la disputa por la vía al

\footnotetext{
${ }^{39}$ Miguel Urrutia, y Londres 38, Los retornos del poder popular: el MIR y el cordón cerrillos Maipú. 19721973, mimeo. Miguel Urrutia, Prácticas de politización y poder popular en Chile, Londres 38, mimeo, 2012.

${ }^{40}$ Programa de la Unidad Popular, 1970, pp. 14-25.

${ }^{41}$ Theotonio Dos Santos, "socialismo o liberación en el Programa de la Unidad Popular", En: Chile Hoy, año 1, no. 1, del 16 al 22 de junio de 1972, p. 4.

${ }^{42}$ Rolando Álvarez, "La unidad popular y las elecciones presidenciales de 1970 en Chile: la batalla electoral como vía revolucionaria", en OSAL, Buenos Aires: CLACSO, año XI, no. 28, noviembre, 2010.
} 
socialismo, los ritmos del proceso, la amplitud de la alianza política y los elementos estratégicos en la consecución de los objetivos del programa.

Esta ha sido caracterizada de distintas formas: como un Frente Popular de Nuevo Tipo ${ }^{43}$ como un frente de carácter pluriclasista con hegemonía del reformismo obrero; ${ }^{44}$ como un frente pluriclasista bajo influencia de la pequeña burguesía; ${ }^{45}$ o como una articulación que expresa una solución de compromiso entre tendencias pequeño-burguesas y reformistas, con sectores obreros revolucionarios. ${ }^{46}$ La dificultad de este proceso radicó en el carácter de la alianza de clases que se debía construir y el rol fundamental que jugaron en ese proceso las "capas medias" como agentes de consenso. Discusión que está en la base de la disputa entre la tesis de "Frente de Trabajadores" (PS) y la de "Frente de Liberación Nacional" (PC), sobre todo en lo concerniente a los aspectos estratégicos que se expresan en la discusión sobre la "vía chilena al socialismo".

El debate sobre el poder popular se concentró en distintos momentos y constituye un buen ejemplo para dar cuenta de las modificaciones en desarrollo en la cultura política de la izquierda chilena, además de los vacíos estratégicos en la formulación de la vía chilena al socialismo, más allá de las fórmulas eclécticas de la especificidad de la "de la vía chilena al socialismo" como una suerte de "reformismo-revolucionario". 47

Las principales referencias al poder popular se efectuaron en el programa de gobierno de la Unidad Popular, durante el proceso de campaña y el principal protagonista fue Salvador Allende. Luego la discusión continuó a raíz del desborde de la movilización de fracciones de trabajadores, que presionaron en la ampliación de las empresas del Área de Propiedad Social, que decantarán en la formación del cordón industrial cerrillos, el surgimiento de la Asamblea de Concepción, ${ }^{48}$ el Manifiesto de Linares y la creación masiva de los Cordones Industriales y Comandos Comunales hacia octubre de 1972.

El grueso de la discusión y la experiencia se generó entre el paro de Octubre de 1972, hasta el fallido golpe de Estado del 29 de junio de 1973, para finalmente, concluir con una disputa explícitamente política, a partir de agosto hasta el golpe del 11 de septiembre.

En estos momentos los principales protagonistas del debate fueron los líderes de los respectivos partidos políticos, intelectuales, analistas y organizaciones de trabajadores, sobre el tamiz del aumento de las movilizaciones y de la conflictividad social. En este momento observamos que se va generando un espacio público subalterno, ${ }^{49}$ que modifica

\footnotetext{
${ }^{43}$ Cancino, op cit.

${ }^{44}$ MIR, El MIR y las elecciones presidenciales, 1970.

45 Carlo Mistral, "Clases sociales en Chile y la dirección política de la Unidad Popular”, En: Unidad Proletaria, 1978

${ }^{46}$ Gabriel Smirnow, La revolución desarmada, 1970-1973, México D.F, ERA. 1977.

47 Álvarez, op. cit., p. 222 y p. 237.

${ }^{48}$ Danni Monsálvez, "La Asamblea del Pueblo en Concepción. La Expresión del poder popular". Revista de Historia, Número 2, 2º semestre, Volumen 16, Concepción, año 2006.

${ }^{49}$ Por espacio público subalterno nos referimos a la emergencia de diferentes actores, organizaciones e intelectuales que comienzan a generar un espacio de deliberación público a través de canales alternativos a a los tradicionales medios de comunicación de masas y prensa escrita. Por subalternos nos referimos a que los principales protagonistas de este proceso fueron las organizaciones, militantes e intelectuales alineados con el
} 
las características restrictivas de subjetivación política y va ampliando los espacios de reflexividad y debate, dado que las prácticas de movilización van transformándose y ampliándose a partir del protagonismo llevado adelante por las clases subalternas chilenas, lo que permitió generar nuevos espacios de subjetivación política y movilización social que modificaron el modo tradicional de relación entre lo social y lo político puesto en marcha desde 1938.

\section{a) El programa de Gobierno, los Comités de la Unidad Popular y Salvador Allende.}

En el programa de la U.P. la referencia al poder popular se expresa en la formación de los Comités de Unidad Popular, concebidos como organismos electorales y "como intérpretes y combatientes de las reivindicaciones de las masas" [que las] prepararán para ejercer el Poder Popular. Así, pues, este nuevo poder que Chile necesita debe empezar a gestarse desde ya, donde quiera que el pueblo se organice para luchar por sus problemas específicos y donde quiera que se desarrolle la conciencia de ejercerlo". 50 Se conciben teóricamente en el programa de gobiernos como gérmenes de poder popular. Sin embargo la vaguedad en términos de la forma que estos adoptarían va en sintonía con la vaguedad en la que es comprendida y teorizado el poder popular. Por el contrario, parece más bien una consideración del mismo en el repertorio clásico de combinación de trabajo de masas como preparativos para la contienda electoral. Esta combinación de lucha electoral y trabajo de masas constituye, como bien señala Rolando Álvarez, una práctica y un discurso recurrente por parte de la izquierda tradicional. La novedad de esta acepción, lo constituye la vaguedad del lugar que se les dará a estos organismos en una eventual victoria del Gobierno Popular, durante el desarrollo de las transformaciones políticas y económicas. ${ }^{51}$

En ese sentido, la novedad que expresa esta nueva forma de organización recibe una referencia estratégica que queda sin una especificación, pero que podemos concluir que se refería a las transformaciones político-institucionales que se generarían en el Estado Capitalista de Compromiso y la manera en cómo se expresaría este proceso de transformaciones en relación al desarrollo del poder popular.

En el diseño del programa de gobierno, el poder popular quedó referido a una combinación de elementos de poder económico y político que, mediante las transformaciones económicas (Área de Propiedad Social) y democratizadoras de la institucionalidad (Estado Popular), constituirán una vía para la generación de un espacio

gobierno de la Unidad Popular e identificados con las clases subalternas chilenas. Este espacio público comienza a ser identificado como tal por los mismos dirigentes sindicales y teóricos del proceso. Al respecto, véase: Víctor

Vargas Espinoza, "Los trabajadores y la prensa de izquierda", Chile Hoy, no. 10, año I, semana del 18 al de agosto de 1972, p. 2. Aurelio Oses,. "Orientación de la prensa de izquierda", Chile Hoy, no. 11, año I, semana del 25 al 31 de agosto de 1972, p. 2.

${ }^{50}$ Programa de la Unidad Popular..., op. cit., p. 11.

51 Jorge Larraín y Fernando Castillo, "Poder Obrero-campesino y transición al socialismo en Chile", CEIREN, no 10, diciembre de 1971, pp. 161-198 
que posibilitase un proceso de transferencia de poder. Esta transferencia de poder iría desde el bloque en el poder, hacia la alianza de clases que sustentaba el diseño político de la unidad popular: es decir, a los trabajadores de la ciudad y el campo, capas medias y burguesía no-monopólica de carácter progresista. Así, en el acápite sobre el Poder Popular se señala:

las transformaciones revolucionarias que el país necesita sólo podrán realizarse si el pueblo chileno toma en sus manos el poder y lo ejerce real y efectivamente, (...) para lo cual es necesario el traspaso de poder, de los antiguos grupos dominantes a los trabajadores, al campesinado y a sectores progresistas de las capas medias de la ciudad y el campo ${ }^{52}$

De la suma del control de poder político y económico, al menos en el programa, se comprende la posibilidad de consecución de los objetivos que este se traza:

la garantía del cumplimiento de esos objetivos reside en el control por el pueblo organizado del poder político y económico, expresado en el área estatal de la economía y en la planificación general de estas. Es este poder popular el que asegurará el cumplimiento de las tareas señaladas. ${ }^{53}$

En esta referencia queda en evidencia el vacío en la formulación teórico-estratégica del poder popular. El lugar que se le atribuye al poder popular en este diseño fue de lugar de apoyo a los órganos de dirección en el Estado (a través del poder ejecutivo y el parlamento) y en la sociedad (partidos políticos y organizaciones civiles), desde las participación en distintos niveles en el nuevo Estado a construir por parte de las actores y organizaciones de las clases subalternas.

En ese sentido, en la manera de entender la relación entre Estado (política) y sociedad (su base social) se basa en la distinción entre funciones de dirección y de representación política (soberanía popular), ligadas mediantes organizaciones sociales de masas, como se expresa a continuación:

El gobierno de la Unidad Popular será un gobierno fuerte, no en el sentido policial y represivo, sino por la solidez y definiciones de sus principios, su política, su programa, por su amplia base social, por la coordinación constructiva de las fuerzas políticas que lo integran, por el apoyo resuelto del pueblo, que ejercerá el poder a través de sus partidos y de sus organizaciones sociales representativas en diversas instancias y niveles. ${ }^{54}$

En definitiva, los CUP como embriones de poder popular en gestación habrían surgido de la incorporación progresiva de los representantes del pueblo en las instancias del Estado,

\footnotetext{
${ }^{52}$ Alvarez, op. cit., p. 12.

${ }^{53}$ Ídem, p. 25.

${ }^{54}$ Ídem., p. 38.
} 
instalando el conflicto de poder en su interior, paralela al apoyo en la base del movimiento de masas articuladas a los partidos políticos y sus formas de organización tradicionales: sindicato industriales y agrícolas, juntas de vecinos, espacios asociativos multifuncionales. ${ }^{55}$

Estas caracterizaciones generadas en el Programa distaron mucho del rol que efectivamente cumplieron los CUP, los cuales se disolvieron a mediados del primer año de gobierno, al no identificárseles funciones y objetivos claros. Esta situación, para algunos analistas y partidos de la época expresaba la tendencia hacia la burocratización de estas herramientas. ${ }^{56}$

Como Señala Rolando Álvarez, si los CUP se convertirían o no en órganos de poder popular, requería de un debate político y teórico que las urgencias de la campaña hacían imposible realizar. Así "la existencia de los CUP como supuestos embriones de "poder popular" quedó sólo como un enunciado general, como letra muerta, al no haberse efectuado una discusión de fondo dentro de la UP sobre este crucial punto." ${ }^{57}$

La hipótesis de Álvarez al respecto es plausible sobre el carácter "tradicional” de los CUP's como herramientas electorales, y parece una concesión del PC a sus aliados socialistas que, desde 1965 identificaban teóricamente en el surgimiento de un "poder revolucionario y la movilización de masas, el fundamento que les permitiese articular lucha electoral con el objetivo estratégico de la conquista del poder. ${ }^{58}$ En ese sentido, en el partido liderado por Carlos Altamirano, desde 1965 en adelante, comienza a generarse una aproximación teórica hacia el problema del "momento revolucionario" y del surgimiento de un "poder de base popular" como un fundamento revolucionario. Esta referencia a nivel estratégico sigue una formulación teórica vaga, sin relaciones a expresiones concretas dentro de los espacios de subjetivación y movilización popular, pero constituye al menos una voluntad política que intuitivamente refiere a un vacío en la formulación sobre la vía chilena al socialismo.

Esta ambigüedad en las consideraciones estratégicas expresa la peculiaridad del PS como un partido de tendencias en disputa interna. Allende en ese sentido es un representante del ala moderada al interior del PS y que está en el fondo de las dificultades que tuvo que afrontar para ser proclamado candidato en 1970. Esta vaguedad de comprender la definición estratégica, se traslapa a la comprensión del poder popular a la que su sector va adscribiendo. Esta manera de entender el poder popular por Allende está en las antípodas de una concepción más cercana a la definición de dualidad de poderes, próxima al ala de la "izquierda revolucionaria", que decantará hacia finales del proceso.

\footnotetext{
55 Este análisis está en la base de la "dualidad de poderes al interior del estado", que enfrenta al ejecutivo contra los otros poderes del Estado. Sergio Ramos, ¿Chile, una economía en transición?, La Habana, Casa las Américas, 1972.

${ }^{56}$ Marta Harnecker, "Reflexiones sobre el Gobierno de Allende. Estudiar el pasado para construir el futuro". http://biblioteca.clacso.edu.ar/clacso/otros/20111026114216/allende.pdf”" (consultado el 12/1/2014)

57 Álvarez, op. cit., p. 225.

${ }^{58}$ Gaudichaud, op. cit., p. 25.
} 
Esta manera de entender el poder popular quedó claro durante la campaña electoral de 1970 y en el famoso discurso del 5 de septiembre de 1970 en la FECH, al ser proclamado presidente por sus seguidores. Por otra parte, su distancia con la noción de dualidad de poderes, se expresó en la carta enviada a los jefes de los partidos políticos de la UP, el 31 de julio de 1972, publicada en la revista teórica del partido comunista ese mismo año. ${ }^{59}$

Durante la campaña, Allende se refirió al poder popular en los siguientes términos. En un discurso en Arica, Allende explicaba como comprendía el proceso político: "queremos la revolución, que la entendemos y capacitaría, llevando al pueblo al poder". 60 Para el candidato, el protagonismo y la participación popular eran fundamentales: “(...) la lucha nuestra es para que ustedes, los trabajadores, sean gobierno. Que ustedes puedan participar en las empresas en las que trabajan a través del Consejo de Economía", ${ }^{61}$ desde donde podrán "ejercer los deberes y derechos irrenunciables que les corresponden dentro de la construcción de la nueva sociedad chilena y como principales protagonistas del Poder Popular". ${ }^{62}$ Los términos y alcances sobre los niveles de participación y los grados de protagonismos no fueron formulados en específico, lo que es comprensible por la situación enunciativa de un discurso presidencial, replicándose los vacíos del programa de la UP en los cuales, se identificaba a las organizaciones tradicionales del movimiento popular como los espacios de integración al gobierno.

Esta situación irá revirtiéndose desde que es electo presidente, tribuna desde la cual aclarará los alcances del poder popular. En su primer discurso presidencial del 21 de mayo de 1971, ante el congreso pleno, el presidente aclarará: "El Poder Popular Significa que acabaremos con los pilares donde se afianzan las minorías que desde siempre condenaron nuestro país al subdesarrollo". 63

Como se aprecia el posicionamiento queda formulado en términos más de apoyo y de orientación socioeconómica, que política. Será ese componente de subjetivación y movilización política el que irá progresivamente tomando mayor relevancia en el debate a medida que las formas clásicas de mediación y movilización vayan siendo superadas por la experiencia del propio movimiento popular.

Al contrastar el desarrollo cuantitativo del movimiento de masas con el desarrollo de la coyuntura política, podemos identificar que la tensión política aumenta en el bloque socialista a medida que el proceso se va radicalizando, desde la perspectiva de la movilización social, lo cual termina esclareciendo las diferencias en las formulaciones políticas de carácter estratégico que están latentes en la formulación del poder popular.

Los análisis estadísticos muestran que entre 1970, 1971 y 1972 se genera un amento explosivo de la movilización de masas en la que irrumpen actores no tradicionales en la

\footnotetext{
${ }^{59}$ Principios, no. 146., pp. 113-126. La revista Chile hoy, publicó un fragmento de esta misiva. Chile Hoy, año 1, del 4 al 10 de agosto. no. 8. p.6. Sobre la polémica PC-MIR, Punto Final, Año VI, martes 6 de junio de 1972.

${ }^{60}$ El Siglo, 1 de marzo de 1970.

${ }^{61}$ El Siglo, 14 de agosto de 1970.

${ }^{62}$ El Siglo, 2 de mayo de 1970.

${ }^{63}$ Salvador Allende, Primer Mensaje Presidencial, 1970.
} 
práctica política del movimiento obrero, como son la pequeña y mediana industria y el sector comercio. En 1970 según la estadística utilizada por Ruy Mauro Marini ${ }^{64}$ se registran 1819 huelgas. Esta cifra en 1971 aumenta a 2709 y p,ra el primer trimestre del 1972, se registran 763 con una proyección de 3526. Esto supone un aumento para el año 1971 de un $48 \%$ en la movilización y, para el año 1972, de un 30,1\%.

Esta tendencia al alza en la movilización, cuando es contrastada con el número de trabajadores movilizados por empresa da cuenta de una disminución del tamaño de las unidades productivas en conflicto, lo que supone una entrada a la movilización obrera de los sectores manufactures, del comercio y los servicios de pequeña y mediana envergadura. Esto se expresa en la disminución neta del número de trabajadores en huelga, que pasa de 647 mil en 1970, a 292 en 1971, lo cual constituye una disminución del 54,8\%. Mientras que el número de conflictos aumenta en ese año en $48,9 \%$, lo cual implica que esa disminución del número de trabajadores por unidades productiva sólo se justifica por la inclusión en la movilización de pequeñas y medianas unidades productivas.

Cuando se contrasta esta información con el pulso de la lucha de clases, en relación a la coyuntura, se puede dar cuenta de la doble relación existente entre la radicalización de la movilización de masas y de la necesidad de generar mayores claridades políticas en torno tanto: 1) al rol jugados por el movimiento de masas en el proceso; 2) como los vacíos en la formulación estratégica expresada en la discusión en torno al poder popular.

Estableciendo una periodización en base a semestres entre 1971 y 1972, identificando las principales hitos de la coyuntura política, se pueden identificar tres fases políticas.

La primera constituye una la fase de ofensiva y consolidación por parte del gobierno, que corresponde al primer semestre de 1971, donde se presenta una correlación de fuerzas políticas favorable a la izquierda. La segunda fase correspondió a un momento de transición, cuando el crecimiento de la base social del gobierno empieza a desacelerarse, a demostrar sus límites. Este proceso coyunturalmente va desde la elección complementaria de Valparaíso en junio de 1971, hasta la marcha de las mujeres en diciembre de 1971. Finalmente la tercera comienza con la crisis política de 1972, cuando comienzan a emerger nuevas formas de asociación y movilización, que demuestran el deterioro de la dirección política y el despunte de las clases subalternas. Desde ese punto en adelante, la discusión del poder popular asume una centralidad en el debate del campo político de la izquierda, lo que nos hace intuir que las ambigüedades en la orientación estratégica de la vía chilena al socialismo y la radicalización de las formas de movilización social modifican el campo político de los partidos de la Unidad Popular.

La discusión se inicia durante el año 1972 a raíz de un cambio en las correlaciones de fuerzas políticas, el reagrupamiento de la oposición favorecida por el asesinato de Edmundo Pérez Zujovic el 8 de junio de 1871 y la entrada con fuerza de la movilización de masas tanto por parte de la oposición, como de la base social de la UP. La oposición inicialmente, se aglutinó en torno al establecimiento de la "estrategia de los mariscales

\footnotetext{
${ }^{64}$ Ruy Mauro Marini Antecedentes para el estudio del movimiento de masas en el periodo, mimeo, 1976.
} 
rusos", ${ }^{65}$ la cual comprendía una posición de defensa de la constitución de 1925, de la propiedad privada y de sabotaje económico, que propiciara la generación de una opinión desfavorable a la UP en el interior de las Fuerzas Armadas. Al mismo tiempo que intentaba establecer una reforma constitucional (Reforma Hamilton-Fuentealba) que cercara al gobierno y detuviese la política de expropiaciones.

Los partidos de la UP, conscientes de estas variaciones y de las deficiencias de una falta dirección política homogénea, ${ }^{66}$ caen a nivel de las articulaciones partido-sociedad en la tentativa de construcción de un Partido Federado de la Unidad Popular (que al final no llegó a materializarse) y, a nivel de la conducción, comienzan a generar una disputa en el establecimiento de una línea común, la que está presente en la tensión entre la táctica de "consolidar para avanzar" o de "avanzar sin tranzar". Sin embargo, estos esfuerzos no lograrán relevarse como suficientes, ante el despunte antagonista del movimiento popular, que comenzó a ampliar sus espacios de movilización y subjetivación política, dando cuenta de la crisis de articulación de fuerzas sociales en la que el bloque socialista fue progresivamente desplazándose.

\section{b) La Asamblea Popular de Concepción}

La tensión estalla desde la radicalización de una fracción de trabajadores de CerrillosMaipú, quiénes tras una serie de experiencias movilización durante los meses de junio y julio generaron un nuevo espacio de articulación y politización: el Cordón Industrial. A lo que podemos agregar la polémica generada al interior de la UP con el llamado a convocar una serie de Asambleas en Concepción, que culminarán tras la tercera convocatoria del 22 de julio con la presentación de un Manifiesto. ${ }^{67}$

Tras esa asamblea, el jueves 27 de julio nació en Concepción la Asamblea del Pueblo, apoyada por los Partidos Socialista, MIR, MAPU, Izquierda Cristiana y Radical. En la convocatoria a la formación de la asamblea se señalaba:

Se convoca al pueblo a discutir, analizar y denunciar, directa y democráticamente, la función y carácter contrarrevolucionario del Parlamento. Se convoca al pueblo, al mismo tiempo, a rendir un combativo homenaje a la Revolución Cubana, cuando se cumple un nuevo aniversario de la gesta del 26 de Julio. ${ }^{68}$

\footnotetext{
${ }^{65}$ Claudio Orrego, "La elección presidencial de 1970”, Política y espíritu, no. 332, mayo de 1972 , p. 7. Citado por Marta Harnecker, "Fuerzas en Pugna", Chile Hoy, año 1, no. 21, del 3 al 9 de noviembre, 1972, p. 15.

${ }^{66}$ Luis Corvalán, "Estamos viviendo una crisis de orientación política”, El Siglo, 26 de Mayo de 1972. Izquierda Cristiana, "Las definiciones de la U.P. confunden a las masas", En: Punto Final, año VI, no 162, martes 18 de julio, 1972 pp. 4-5.

${ }^{67}$ Chile Hoy, no 8, año 1, del 4 al 10 de agosto, pp. 6-7. Harnecker, Marta, "la Asamblea Popular de Concepción", Chile Hoy, año 1, no. 12, del 1 al 7 de septiembre de 1972, pp. 5-6. FMP, "La asamblea del pueblo, respuesta al Parlamento Burgués”, Punto Final, año VI, 1 de agosto, 1972, no. 163 pp. 6-7.

${ }^{68}$ Asamblea del Pueblo: respuesta al parlamento burgués, Punto Final, no. 163, Año VI, 1 de agosto de 1972.
} 
En dicha oportunidad, Salvador Allende precisa su posición en relación al poder popular en términos tajantes. A partir de este momento, registramos en la prensa de izquierda y en la opinión pública mayores elementos sobre este tema que decantará en la generación de mayores claridades al debate, ${ }^{6}$ supliendo una falencia estratégica de consideración en la elaboración de la vía chilena al socialismo, sobre todo lo correspondiente al problema del poder, las vías y la relación entre gobierno popular y transición socialista.

Allende, parte desautorizando la ida de la existencia de enfrentamiento de poderes contra la institucionalidad y señalando que la disputa de poderes se instala al interior del Estado (una formulación similar a la utilizada por Sergio Ramos) ${ }^{70}$ En esa misiva, Allende señala:

El poder popular no surgirá de la maniobra divisionista de los que quieren levantar un espejismo lírico, surgido del romanticismo político al que llaman, al margen de toda realidad, "Asamblea Popular". Señalando a continuación que, "una Asamblea Popular auténticamente revolucionaria concentra en ella la plenitud de la representación del pueblo. Por consiguiente, asume todos los poderes. No sólo el deliberante sino también el de gobernar. ${ }^{71}$

En relación a la "dualidad de poderes", Allende señala que éste ha surgido en ocasiones en las que se ha instalado un gobierno reaccionario sin base social. ${ }^{72}$ Para señalar, finalmente, que el principal espacio de disputa de poder se dará entre el ejecutivo y el parlamento, de ahí la centralidad en establecer una mayoría parlamentaria en marzo de 1973.

Esta contradicción entre las expresiones formabas al calor de las movilizaciones y las inconsistencias sobre el poder popular en el programa posibilitaron que dirigentes regionales de los partidos de la UP, junto con dirigentes sindicales ampliaran la manera en cómo se llevaba adelante el poder popular. El dirigente regional del PS de Concepción, Rafael Merino en conferencia de prensa evidenció estas tensiones entre las dirigencias locales, el movimiento popular y la dirección de la UP. Merino señaló, en relación a la asamblea que

Está, en el Programa de la UP y, además, forma parte de la política del Partido Socialista. El último Pleno del Comité Central confirmó que se

\footnotetext{
69 "Debate sobre el poder: nuevos elementos", Chile Hoy, año 1, no. 12, del 1 al 7 de septiembre de 1972, p. 4-5.

${ }^{70}$ Ramos, op. cit.

${ }^{71}$ Salvador Allende, "El Poder Popular no surgirá de maniobras divisionistas", Revista Principios no. 146, 1972, p 120-123.

${ }^{72}$ Salvador Allende, "El Poder Popular no surgirá de maniobras divisionistas", Revista Principios no. 146, 1972, p 120-123.
} 
llamaba a desarrollar nuevos organismos de decisión a nivel comunal y provincial. Concretamente se pidió crear los Consejos Comunales Urbanos. Creemos que el PC puede expresar su opinión como partido, pero la declaración de una colectividad no va a cambiar la decisión de la UP. Fue el MAPU el que hizo el primer llamado a la Asamblea del Pueblo. Incluso, puedo asegurarles que se estuvo en conversaciones con todos los partidos de la UP para ver la posibilidad de llamar a esta Asamblea. De esto hace bastante tiempo. El PC dio las mismas razones que aparecen en la prensa para negarse. ${ }^{73}$

En una sintonía similar, el MAPU de la región de Concepción, también enfatizó estas tensiones y en el comunicado de apoyo a la formación de la asamblea popular: "De la realización y el éxito de dicha Asamblea, depende en una medida muy grande, que el proceso revolucionario en nuestra región se desarrolle, no por cauces burocráticos o paternalistas, sino en conformidad a una correcta línea de masas". ${ }^{74}$ Sin embargo, precisó que un tono de alerta en contra la presencia de la instrumentalización que la derecha y la ultraizquierda podrían hacer de dicho proceso.

Por su parte el MIR, señaló la formación de la Asamblea de Concepción se constituyó como un espacio de deliberación, intercambios de experiencias y de resolución de problemáticas locales. Agregando que si el "pueblo habla por sí mismo y para sí mismo, el pueblo comienza a hacer poder". 75 Agregando que esta experiencia de organización constituye una expresión de poder popular:

Este poder popular inevitablemente se opone en la única forma posible al poder que la burguesía mantiene en el Poder Judicial, en la burocracia y, principalmente, en el Parlamento. Es en ese Parlamento donde todas las iniciativas que busquen favorecer a las masas serán sepultadas una a una. Es en ese Parlamento donde se yergue el principal poder del imperialismo y la reacción. ${ }^{76}$

Por su parte, Mario Benavente, miembro del Comité Central del Partido Comunista, trazó una línea clara de rechazo a esta expresión de organización y subjetivación subalterna, indicando que para ellos "esta es una maniobra que la reacción y el imperialismo están impulsando, valiéndose de elementos de ultraizquierda y en particular del MIR, con su rama el FTR",77

Los efectos teóricos y políticos de esta experiencia de organización, movilización y subjetivación política tuvieron efectos en el campo político. Por este motivo en la editorial

\footnotetext{
73 “Asamblea del Pueblo: respuesta al parlamento burgués”, Punto Final, no. 163, Año VI, martes 1 de agostos de 1972

${ }^{74}$ Ibídem.

${ }^{75}$ Ibídem,

${ }^{76}$ Ibídem,

77 "Polémica en la Izquierda- La "Asamblea Popular" de Concepción", Chile Hoy, no. 8, Año I, Semana del 4 al 10 de agosto, p. 6.
} 
de la Revista Chile hoy no. 8, se dedicaron tres columnas a la problemática del poder popular, la participación y el poder.

Entregando antecedentes sobre la problemática de la dualidad de poderes y el poder popular, Theotonio Dos Santos constata que la discusión sobre la dualidad de poderes se genera en la medida en que el movimiento popular a través de la movilización pone el problema del poder a la orden del día. Para luego afirmar que:

las formas de poder popular que están naciendo en Chile no constituyen aún un poder paralelo al estado burgués (...), dado que ellas "tienen fundamentales objetivos locales y específicos de carácter esencialmente administrativo. Les falta función legislativa, judicial y carácter nacional para constituirse en un poder paralelo ${ }^{78}$

Enfatizando, la necesidad de que estos embriones de poder se planteen coordinación desde la base a nivel local y con proyección provincial, articulándose con el gobierno popular que ha iniciado en los canales de la legalidad burguesa, la destrucción del poder monopólico nacional, internacional y el latifundio. En ese sentido la existencia del poder popular desde abajo, ante el apoyo del poder desde arriba, favorece formas de articulación complementarias a las tareas de gobierno contra los enemigos centrales establecidos en el programa.

En esa misma línea, Pío García enfatiza que "si la UP no ofrece con decisión y claridad la dirección que se requiere para el cumplimiento de las tareas revolucionarias, las masas intentarán encontrarla por sí mismas, abriendo pasos al riesgo de desviaciones" 79

Las tensiones evidenciadas en el desarrollo de la Asamblea Popular de Concepción nos dejan en evidencia al menos tres aspectos importantes. El primero de ellos, dice relación con la manera en que las direcciones regionales de los partidos eje de la UP comenzaron a evidencia algunas tensiones en la implementación del programa de la UP, originadas en la inconsistencia y en la ambigüedad de la formulación del poder popular como curso estratégico. El segundo, pone en evidencia el surgimiento de un espacio de reflexión, crítica y elaboración colectiva de las experiencias de subjetivación de las clases subalternas en la formación de un emergente espacio público subalterno. Lo tercero, lo que señala la historiadora Sandra Castillo como "un apoyo crítico al gobierno, lo que se tradujo en una lectura distinta de la "vía chilena". Una lectura "desde abajo". 80

\footnotetext{
${ }^{78}$ Theotonio Dos Santos, "Sobre la dualidad de poderes", Chile Hoy, año 1, no. 8, del 4 al 10 d agosto de 1972, op. cit., p. 4.

${ }^{79}$ Véase también: Pio García, "la vía democrático-revolucionaria”, Chile Hoy, no. 8, año 1, del 4 al 10 d agosto de 1972, pp. 4-5.

${ }^{80}$ Castillo, Sandra. op. cit, p. 136.
} 
Pablo Seguel, Prácticas de poder de las clases subalternas en el desarrollo del poder popular en Chile, 1967-1973 Political subjectivization practices in the development of the popular power in Chile, 1967-1973, Revista Izquierdas, 27 , abril 2016, ISSN 0718-5049, pp. 161 - 199

\section{c) Para patronal de octubre de 1972 y la formación de un espacio público subalterno.}

El tercer momento del debate del poder popular se entronca en el contexto de ofensiva de la derecha y el viraje de la Democracia Cristina hacia las tácticas golpistas y se manifiesta durante el Paro Patronal de Octubre. En ese momento, la iniciativa desde la base social en respuesta a la ofensiva de la oposición decantó en la generación de un espacio público subalterno para el esclarecimiento de las acciones a seguir por el conjunto de las organizaciones sociales movilizadas. Este fenómeno que surge con la masificación de los Cordones Industriales y de los Comandos Comunales, revive la discusión sobre el poder popular, su relación con el Gobierno, los partidos políticos y la problemática de la transición de poder desde el gobierno popular hacia la forma de Estado socialista.

Para un periodista de la Revista Chile Hoy apunta que a lo largo del Paro de Octubre, el “pueblo avanzó más en ese periodo crítico que en los años del gobierno popular". ${ }^{81}$ En ese mismo sentido, tanto los partidos, como las organizaciones sociales participantes en la conformación de los comandos coincidieron en señalar que éstos constituyeron "organismos de poder en el seno de las masas". 82 Estos surgieron de forma espontánea como respuesta del pueblo ante la ofensiva de la oposición. Su objetivo fue coordinar todas las acciones en la comuna para vigilar, prevenir el sabotaje, asegurar la distribución de alimentos y bienes esenciales, el transporte, el abastecimiento de las materias primas.

Los Comandos Comunales surgieron en este contexto a partir de la experiencia de los Cordones Industriales. Según el PS, nacieron para "enfrentar la sedición reaccionaria y para coordinar la lucha por normalizar la actividad económica y social de cada localidad", 83 conformando una verdadera alianza de diversos actores de las clases subalternas. En palabras de Manuela Manami, miembro del Coordinador de San Miguel: "Aquí están integrados los pobladores, JAP, centros de Madres, Organizaciones Juvenil, Juntas de Vecinos, obreros y estudiantes". ${ }^{4}$

Para Mami estos comités organizaciones multisectoriales de presencia territorial se formaron a nivel de base, como expresiones de poder ante las problemáticas del paro. Al respecto señala que "Los trabajadores hemos visto que organizados a nivel de base se han creado organismos de poder que les van planteando alternativas a la solución de sus problemas, que son muchos" 85

\footnotetext{
${ }^{81}$ V.V. "Los Comandos Comunales: iniciativa de las masas", Chile Hoy, año 1, no 26, semana del 8 al 14 de diciembre de 1972, p.15.

${ }^{82}$ Marta Harnecker, "los comandos comunales y el problema del poder", Chile Hoy, año 1, no. 26 , del 8 al 14 de diciembre de 1972, no p. 4. VV. "Comandos Comunales", Chile Hoy, año 1, no. 26, del 8 al 14 de diciembre de 1972, p. 15, Faride Zerán, "Las bases opinan”, Chile Hoy, año 1, no. 26, del 8 al 14 de diciembre de 1972, pp. 16-17. "la izquierda hace su balance", Documentos. Suplemento a la edición Punto Final, año VII, 19 de diciembre de 1972, p. 21. A. Carmona, "Comités Coordinadores: Rutas del Poder Obrero", Punto Final, Año VII, 21 de noviembre de 1972, pp. 26-29.

${ }^{83}$ Declaración del Partido Socialista del 22 de octubre de 1972.

${ }^{84}$ Zerán, op. cit., p. 16.

${ }^{85}$ Ibídem.
} 
En relación a su perspectiva de poder, Ricardo López, trabajador de la industria FENSA de la comuna de Maipú señaló: "[Los Comandos Comunales] nacieron por la necesidad de responder a la embestida de los patrones, y no por la de organizarse y construir un poder de las bases". ${ }^{86}$ López señala que en la misma base de los comandos se efectúan alianzas de diversos partidos y organizaciones, enfatizando que estos surgieron como respuesta a la coyuntura del paro: "ellos nacieron por la necesidad de responder a la embestida de los patrones y no por la de organizarse y constituir un poder de las bases"

Una posición similar y que sintetiza los orígenes de los comandos, las tareas que emprendieron y la alianza política que llevaron adelante la expuso en del dirigente sindical de Conchalí, Miguel Mata:

El Coordinador surgió como producto de los problemas político que vivimos el mes pasado, cuando los trabajadores nos tomamos las industrias que los patrones habían abandonado, cuando decidimos echar a andar el país. Entonces nos unimos todos: pobladores, estudiantes, obreros y hasta campesinos, y participaron compañeros del MAPU, PC, PS, IC y del MIR ${ }^{88}$

Para los partidos políticos eje de la UP (PS-PC), en un documento conjunto señalaron el enorme potencial de la movilización de masas y la necesidad de articularlos con las instituciones y organismos tradicionales (La CUT y el ejecutivo): "hasta hoy sólo hemos utilizado una pequeña parte del potencial combativo de las masas; pensamos que hay que estructurar una táctica de movilización que libre este potencial". En específico, en relación a los comandos comunales, estos los comprendieron como: "organismos de poder en el seno de las masas que sin entrar a suplir los organismos de poder del Estado, canalicen las inquietudes y problemas de los trabajadores y del pueblo en general". 89

Esta posición a grandes rasgos es ratificada en el pleno del comité central del PS y en el del PC, en el que los comunistas señalaron que "la parte del poder conquistado por el pueblo puede desarrollarse y fortalecerse a condición de vincular estrechamente la acción estatal a la acción de las masas populares". 90

La única divergencia, de consideración más en términos estratégicos que tácticos la introduce el MIR al señalar, mediante Nelson Gutiérrez, que los Comandos Comunales constituyen:

Los órganos embrionarios de un poder alternativo, que debe afirmar orgánica, ideológica, programática y políticamente la independencia de

\footnotetext{
${ }^{86}$ Ibídem.

${ }^{87}$ Ibídem.

${ }^{88}$ Ibíd., p. 17.

${ }^{89}$ PS-PC, Propósitos de ofensiva política. Acuerdo PS-PC”. ¡Demos un gran salto adelante! Documentos del Comité Central del Partido Socialista ante el paro empresarial, Santiago, noviembre de 1972, pp. 7-9.

90 Jorge Insunza, "Informe Final del Pleno". Chile Hoy, año 1, no. 26, del 8 al 14 de diciembre de 1972, p.16.
} 
clase del proletariado en su lucha por el Poder". Señalando a continuación, "que en esta concepción el papel del gobierno no se ve como contradictorio, sino como una palanca que debe apoyar el desarrollo de este naciente poder popular. ${ }^{91}$

En una línea similar, en un periódico que comenzó a circular a comienzos de enero de 1973, en los cordones industriales con el nombre de "Tarea Urgente", señalaban la necesidad de:

Unificar por las bases el poder popular", solidificando el poder embrionario que emana de los Coordinadores Industriales, Comandos Comunales, Comités de defensa de la revolución, Juntas de Vigilancia, Comités de Pobladores (...) para lograr el real poder de los trabajadores a través de todos los organismos de base. ${ }^{92}$

La necesidad de otorgar mayores claridades estratégicas, movilizó a sectores de la opinión pública del bloque socialista para generar mayores elementos, encontrar puntos comunes y superar las diferencias. En ese sentido, la deuda estratégica y la ausencia de un espacio público subalterno consolidado, generaron un incentivo para formar este tipo de espacios de diálogo público. ${ }^{93}$ La problemática del poder planteada por la movilización y organización desde la base del movimiento popular, tuvo a nivel político y teórico diferentes respuestas. Tanto intelectuales, ${ }^{94}$ analistas, ${ }^{95}$ militantes de base, personeros de gobiernos, como jefes de partidos se embarcaron en un discusión teórica sin referencias previas en Chile ni en América Latina. La tribuna generada para este esfuerzo de la dirección colectiva del bloque socialista se realizó en los periódicos, prensa de izquierda y en foros.

Una de las expresiones más importantes de la formación de un espacio público subalterno lo encontramos con motivo la celebración del Segundo Encuentro Nacional del movimiento Cristianos por el Socialismo, entre los días 24 y 26 de noviembre. En esa ocasión se efectuó un foro titulado "La Izquierda hace su balance", que contó con la presencia de los principales dirigentes políticos de la izquierda chilena. En esta oportunidad

\footnotetext{
${ }^{91}$ Nelson Gutiérrez, Chile Hoy, año 1, no. 26, del 8 al 14 de diciembre de 1972, p. 17.

${ }^{92}$ Tarea Urgente, año 1, 16 de Febrero, no. 1, p.1

93 "uno de los puntos débiles de nuestro proceso ha sido la falta de planteamientos ideológicos claros y, sobre todo, la incapacidad para discutir a fondo nuestras diferencias ideológicas en el seno de la izquierda". Marta Harnecker, "Los comandos comunales y la polémica en el seno de la izquierda", Chile Hoy, año 1, del 22 al 28 de diciembre de 1972, p. 4. Pío García, "El Poder Popular", Chile Hoy, año 1, no. 31, del 12 al 17 de enero de 1973, p. 4.

${ }^{94}$ Joan Garcés, "Estado burgués y gobierno popular", CEIREN, no. 15, 1973, 132-151. Hugo Zemelman, "la significación del poder popular", CEIREN, no. 17, julio de 1973.

${ }^{95}$ Marte Harnecker, "Los comandos comunales y el problema del poder", Chile Hoy, año 1, no. 26, del 8 al 14 de diciembre de 1972, p. 4. Theotonio Dos Santos, "Comandos Comunales y elecciones", Chile hoy, año1, no. 29, del 29 de diciembre de 1972 al 4 de enero de 1973, p. 4.
} 
asistió Mireya Baltra (PC), Hernán del Canto (PS), Bosco Parra (Izquierda Cristiana, IC), José Antonio Viera Gallo (MAPU) y Miguel Enríquez (MIR) ${ }^{96}$

Hernán del Canto (PS) puso énfasis en las circunstancias que llevaron a la formación del Gabinete Militar, señalando algunas referencias en relación al poder popular, entendido como un poder obrero que permitiría la transición del Estado Burgués al estado Obrero. Así, Del Canto señaló:

Es verdad que necesitamos (...) del poder obrero para desarrollar nuevas formas de poder en este país, para llegar a trasformar este estado burgués en un estado proletario (...) por eso nosotros le asignamos una trascendencia a toda la labor, a todo el trabajo que significa ir concluyendo órganos de poder y por eso le asignamos significación al surgimiento de los comandos comunales como instrumento no de dual de un poder que hoy tenemos, de una parte quizás, sino como instrumento de poder de la clase obrera" 97

La ex-ministra del Trabajo, Mireya Balta (PC), en su exposición criticó el rol de la ultraizquierda, remarcando que el enemigo central de la coyuntura es la amenaza del fascismo. Ahora bien, el rol que el PC le asigna a los órganos de poder popular es de apoyo a la acción del gobierno en contra de la derecha golpista y la amenaza fascista. Por ello, Baltra entiende que "Los comandos comunales, unitarios en cada comuna para coordinar la situación de abastecimiento de y de trasporte". ${ }^{98}$ Es decir, les corresponde una función acotada en tanto los trabajadores son entendidos como una fuerza de apoyo disciplinada "Nuestra clase obrera es un ejército extraordinario, de gran disciplina" 99

Por su parte, para Bosco Parra la problemática de la dirección política de la izquierda se resuelve al interior de los organismos de masas. "los organismos de masas que han nacidos como producto concreto de este enfrentamiento de hoy, son comandos, son consejos, son comités que suministran la base material de la unidad"100

A diferencia de los otros expositores, José Antonio Viera Gallo (MAPU) puso el énfasis de su exposición en los aspectos estratégicos relacionados al contenido del proyecto socialista a construir y al alianza de clases necesaria para ellos, sin hacer una mención explícita a los órganos de poder de las clases subalternas.

Finalmente Miguel Enríquez (MIR), señala las diferencias con los otros expositores en términos de la política de su partido hacia las capas pobres de la ciudad y el campo y de la

\footnotetext{
96 "La izquierda hace su balance", en Documentos. Suplemento a la edición no. 172 de Punto Final, Martes 19 de diciembre de 1972, pp. $21-47$.

${ }^{97}$ Hernán del Canto. "Gabinete Militar: paso táctico de los revolucionarios para llevar al país al socialismo", en Documentos. Suplemento a la edición no. 172 de Punto Final, Martes 19 de diciembre de 1972, p. 24.

${ }^{98}$ Mireya Baltra, "Acción de la clase obrera decidió a las FFAA a incorporarse al gobierno" en Documentos. Suplemento a la edición no. 172 de Punto Final, Martes 19 de diciembre de 1972, p. 28

${ }^{99}$ Baltra, op. cit., p. 27

${ }^{100}$ Bosco Parra, "Es posible extraer dignidad de la escasez y transformar a la pobreza en dignidad", en Documentos. Suplemento a la edición no. 172 de Punto Final, Martes 19 de diciembre de 1972, p. 31.
} 
distinción entre Gobierno y Aparato de Estado, complejizando las relaciones de poder en su interior y de éste con las correlaciones de clases en la sociedad. En relación a los embriones de poder popular, la alianza de clase a construir y el estado como aparato burocrático, Enríquez señala que:

La creación de embriones de poder, por la vía de unir al pueblo, incorporar a los pobres, y desde otro punto de vista más: controlar el aparato del Estado, no al gabinete ahora, sino al conjunto del aparato del Estado como estructura burocrática, constituyendo los comandos comunales $^{101}$

El segundo espacio importante de reflexión y de debate para la izquierda se generó en el foto "El poder popular y los Comandos de Trabajadores", realizado en la casa de la Cultura Gabriela Mistral (Ex edificio de la UNCTAD). En este foro participaron Luis Maira (IC), Víctor Barberis (PS), Pablo Richard (Movimiento Cristianos por el Socialismo, MCS). Miguel Enríquez (MIR) y Oscar Guillermo Garretón (MAPU).

Luis Maira señala que el problema del poder popular se encuadra entre la disputa entre el poder institucional y el poder social. Para Luis Maira el surgimiento del poder popular tiene su expresión en las contradicciones del Estado Capitalista de Compromiso: dentro de la (...) la estructura de la estructura de poder tradicional consagrada en la constitución de 1925, fuerzas populares sean capaces de ganar el control y el ejercicio de unas de las franjas de poder (...) pero al mismo tiempo son violentamente rechazados". ${ }^{102}$. Enfatizando que, en el contexto de la crisis política desatada con el proceso revolucionario esa contradicción estructurante del ECC se manifiesta con fuerza:

Al aparecer esa contradicción, ese conflicto que hoy se vive en la estructura de poder del Estado, en la estructura institucional, se plantea el problema de la aparición de un poder popular. De un poder popular que surge obviamente en la base del pueblo, que se da formas propias y características de organización para resolver sus problemas inmediatos, para imponer al conjunto de la sociedad sus propios intereses de clase. Lo que no es todavía un poder popular consolidado (...) capaz de ejercitar el control del aparato del Estado en su conjunto"103

Al profundizar sobre los orígenes de los Comandos Comunales, Maira enfatiza que estos no fueron el resultado de una anticipación teórica, sino que en "su expresión y en su diseminación desarrollo [fueron la] manifestación muy viva de la inquietud de los propios trabajadores". ${ }^{104}$ Enfatizando, para finalizar, que las características del proceso chileno y el

\footnotetext{
101 Ibíd. 41.

102 "el poder popular y los Comandos de Trabajadores", Documentos. Suplemento de la edición no. 175 de Punto Final, Martes 16 de enero de 1973, p. 2.

103 Ibídem

${ }^{104}$ Ibídem.
} 
desarrollo de las formas de organización de los trabajadores obliga a "plantear de una manera original y creadora las relaciones tradicionales entre el partido, la revolución y la clase" 105

La intervención del MCS no profundizó ni en los orígenes, ni las consecuencias políticas de los comandos comunales ni del poder popular.

Miguel Enríquez, al igual de Maira, hizo alusión al surgimiento del poder popular con el problema del Estado. Sin embargo, a diferencia de Maira, partió aproximando teóricamente al problema del Estado, para luego caracterizar al proceso político chileno como una disputa de poder, de dualidad de poder en una coyuntura pre-revolucioanria. En ese marco, el rol de los Comandos Comunales es "ir estructurando al interior de esta particular situación, órganos autónomos del pueblo, órganos autónomos de clase", independiente del Estado y de la clase dominante. En otras palabras, para el MIR el rol de los Comandos Comunales y de los diversos órganos de poder popular se desprende del proceso general de la revolución y de las diversas fases de la dualidad de poderes.

Se trata de organizaciones que fueran independientes de las clases dominantes, de la burguesía. Se trataba de organizaciones de masas que fueran independientes del aparato del Estado y no que estuvieran sujetas a él. Sin temores y pacateces [SIC] de ningún tipo, dicho claramente, caminar germinalmente hacia la dualidad de poder, que es el único camino que realmente podría ir construyendo un poder alternativo. ${ }^{106}$

Víctor Barberis (PS) también entiende que las expresiones de poder popular en Chile, surgidas de las iniciativas de las clases subalternas son la expresión de una tendencia general de todos los procesos revolucionarios guiados por una dinámica de dualidad de poder.

Todas las revoluciones de la historia, triunfantes o no, han llevado en su vientre el poder dual.

Todas las clases que han insurgido por el poder, han llevado en su seno el germen de la dualidad de poder (...)

Tienen que entender que cuando se comienza a crear el poder dual, la aventura tiene que llegar hasta el fin; y el poder dual y el poder popular solo tienen la alternativa de vencer o de morir. Y es justo, entonces, examinar no solo las condiciones generales, teóricas, en que se está dando, sino las condiciones concretas en que se da, la inserción de la concepción general del poder dual, en la condiciones concretas del caso chileno $^{107}$

\footnotetext{
105 "El poder popular y los Comandos de trabajadores", op. cit., p. 3.

106 "Foro Político...", óp. cit., p. 7.

${ }^{107}$ Ibíd., p 9.
} 
Finalmente, para Oscar Guillermo Garretón (MAPU) el desarrollo del poder popular constituye una clave para comprender el proceso revolucionario, por cuanto "el problema de la conquista del poder presente hoy día, está claro que pasa fundamentalmente por la constitución de todas las formas de poder popular". ${ }^{108}$ Agregando que la conquista del poder ejecutivo constituye un instrumento de la lucha revolucionaria, "un instrumento para apoyar el poder de masas, para desarrollar el poder de masas, para crear ese poder que en definitiva tiene la clave para la construcción del socialismo". Por ello, "el elemento principal del poder popular, y el gobierno como instrumento, tienen que ser considerados en el análisis“. ${ }^{109}$

Desde esta perspectiva, para Garretón los Comandos Comunales constituyen formas de poder popular, que surgieron de la iniciativa de las clases subalternas antes la carencia de una conducción política clara y decidida. En consideración a los elementos estratégicos, Garretón entiende que "el desarrollo de los organismos de este poder popular, que son los Comandos Comunales, son hoy una tarea importante (...) son una tarea principal" 110

Como se observa, en esta fase del desarrollo de la organización de las clases subalternas, en el contexto del deterioro de los canales institucionales para la resolución de las problemáticas políticas puso a la orden del día las relaciones de poder. Un poder que surgió desde una interpretación desde la base social del contenido programático del programa de Gobierno y que se expresó con fuerza en la administración y control de los espacios cotidianos de vida de las clases subalternas chilenas.

\section{d) Entre la victoria de las elecciones parlamentarias del 4 de marzo de 1973, el Tanquetazo y el golpe de estado: el poder popular en acción.}

Las elecciones parlamentarias del 4 de marzo marcaron una inflexión en el desarrollo de la coyuntura. El triunfo de los partidos de la Unidad Popular (43,4\%), los dejó posicionados en un buen pie para avanza en la consolidación del programa de gobierno y generó un contexto de apoyo a las expresiones de poder popular. ${ }^{111}$ Semanas más tarde, entre los días 16 y 18 de marzo, se realizó un encuentro de organizaciones sociales sobre el poder popular y el problema del abastecimiento popular. ${ }^{112}$

En este momento comienzan a observarse una avanzada política por parte de los dirigentes sociales, quienes sin desconocer el apoyo de las organizaciones de base al gobierno popular, comienzan a posicionar un planteamiento crítico sobre el poder popular. Un planteamiento que se aproxima a la integración de las funciones de decisión y deliberación en el seno de la organización popular.

\footnotetext{
${ }^{108}$ Ibíd., p. 12-

109 Ibídem.

110 Ibídem.

111“Al pueblo no lo para nadie”, Documentos. Suplemento a la edición no. 179 de Punto Final, Martes 13 de marzo de 1973.

${ }^{112}$ Chile Hoy, no. 41, Año II, semana del 23 al 29 de marzo de 1973 p. 10. García, Pio. "Avanzar ahora”. Chile Hoy, no. 41., Año II, Semana del 23 al 29 de marzo de 1973, p. 4.
} 
Hacia finales de marzo los partidos eje de la UP efectuaron su balance de la nueva coyuntura política. Oportunidad en la que nuevamente se refirieron al desarrollo de las diversas formas de poder popular, precisando su itinerario estratégico.

Juan Enrique Miquel, subsecretario de la Izquierda Cristiana, se refirió al pleno que su partido sostuvo a finales de marzo. En esa ocasión, su partido le dio un lugar central a las formas de construcción de poder popular autónomas. En sus palabras:

El problema fundamental gira en torno al tema del poder popular, aunque nosotros notamos que el compañero Corvalán, en sus discurso en el Caupolicán, empieza a darle al problema un tratamiento distinto, que hace posible un trabajo conjunto de toda la UP. Nosotros planteamos un poder popular distinto al Gobierno, pero no por ello lo entendemos como un poder antagónico. Se trata de un poder no subordinado al Gobierno. $(\ldots)^{113}$

Luis Corvalán señaló en el balance del pleno del PC, que el poder popular constituía un punto de apoyo al trabajo desarrollado al interior del aparato ejecutivo. Así, Corvalán entendía que en las circunstancias actuales, tras el triunfo de la UP en las elecciones de marzo la tarea era unificar a las organizaciones de masa en apoyo al gobierno.

Que librar al mismo tiempo una lucha contra el burocratismo de este aparato estatal y desarrollar, paralelamente, simultáneamente, todo tipo de organización popular que cumpla aquellas tareas que el aparato burocrático burgués es incapaz de cumplir, y otras que solo puede cumplir eficazmente con el auxilio de la organización popular ${ }^{114}$

Enfatizando que las formas de poder popular no pueden ser antagónicas a las formas históricas desarrolladas por las clases subalternas las que no pueden "ser concebidas y orientada en oposición al Gobierno del Presidente Allende, en oposición a la política del gobierno actual ni pueden tampoco, constituirse con vistas a sustituir otras organizaciones que ha formado el pueblo a través de muchos años de lucha, como son las Juntas de Vecinos, los Centros de Madres o los Sindicatos". 115 Enfatizando que, el desafío político pasaba por trasformar los órganos de poder popular en decisiones vinculantes al interior del Estado "nosotros tenemos que someter la mayoría parlamentaria a la presión de las masas en la lucha por la sanción legislativa de todos aquellos cambios que debe sancionar el Parlamento",116

A diferencia de esta posición, el PS en su pleno del 10 de abril, señaló en palabras de Carlos Altamirano el rol que le correspondía al poder popular. Altamirano comienza señalando que el Gobierno de la Unidad Popular constituye el principal instrumento para la

\footnotetext{
${ }^{113}$ Chile Hoy, año II, 41, semana del 23 al 29 de marzo de 1973, p. 4.

${ }^{114}$ Chile Hoy, no. 43. Año II, Semana del 6 al 12 de abril, p. 28.

${ }^{115}$ Ibídem.

${ }^{116}$ Ibídem.
} 
consecución del programa de gobierno y, que la UP, sigue plenamente vigente como alianza política. Enfatizando que estos dos elementos quedaban articulados a partir del desarrollo del poder popular:

4.- Ambos objetivos solo pueden ser logrados con un desarrollo poderoso de todas las formas de poder popular. Independiente del gobierno, pero no antagónico a este. En ese marco se propone buscar una correlación justa entre Gobierno y masas, que no quite a éstas su iniciativa y capacidad creadora, pero que al mismo tiempo no dificulte la acción de aquel, sino que por el contrario, la favorezca a impulse

5.- Al mismo tiempo, este poder popular debe ir generando una institucionalidad diferente a la burguesa, que permita en determinadas circunstancias oponerse al poder burgués. Para ello el gobierno debe, en la medida que es un gobierno revolucionario, estimular y fortalecer estas nuevas organizaciones de la clase, forjadas al calor de la lucha ${ }^{117}$

En otra intervención, el PS señaló una discrepancia a la posición del PC en relación al carácter subordinado de las organizaciones al gobierno. Para los socialistas "La participación activa de las masas en todas estas organizaciones y su consolidación en torno a tareas concretas que tienen que ver con los problemas directos de la fábrica, el fundo, la población, le hospital o la escuela, aseguran el desarrollo del poder popular alternativo a la institucionalidad burguesa, pero no al Gobierno Popular". Agregando que, "sin depender del Gobierno, el poder popular surgido desde la base lo complementa. Todas las organizaciones de poder popular son importantes, pero en esta fase lo son particularmente las que se dan en el frente económico, donde hay que ganar las batallas de mayor trascendencia $^{118}$

Por su parte, Garretón (MAPU), precisó que el desafío central pasaba por el "desarrollo del poder popular, vale decir, el desarrollo orgánico de un poder alternativo al de la burguesía que crezca al calor de las luchas populares, convirtiéndose así en la fuerza básica para la conquista del poder". ${ }^{119}$

El avance de las formas de organización popular en una línea similar a lo evidenciado en la Asamblea de Concepción, se efectuó el 10 de abril de 1973 en la ciudad de Constitución. En esta oportunidad, el Comando Comunal de Trabajadores ocupó la oficina de la gobernación para llevar adelante el programa de gobierno de la UP. A juicio de los dirigentes, Nelson Luna y Arturo Rivas, "de la tramitación y de la burocracia de las autoridades de Constitución", fueron el argumento que los inclinaron a levantar "una plataforma de luchar que interpreta realmente los intereses y el ánimo del conjunto del pueblo trabajador de Constitución". ${ }^{120}$

\footnotetext{
${ }^{117}$ Ibíd. p. 5.

${ }^{118}$ Chile Hoy, 45, año II, semana del 19 al 29 de abril de 1973, p. 16 y 17.

119 Ibídem.

${ }^{120}$ Chile Hoy 46, Año II, semana del 27 de abril al 3 de mayo, p.9.
} 
La expansión de estas formas de organización popular puso en tensión las relaciones entre la CUt y los Comandos Comunales. Una intervención clara en ese sentido, fue dada por el Secretario General de la CUT, Manuel Dinamarca, quien precisó sobre el rol estratégico del poder popular, indicando que "El comando comunal es una organización nueva que tiende a ir trasladando el poder desde la institucionalidad burguesa a la institucionalidad proletaria. Pero, para que sean organismos de poder, tienen que ser capaces, en la práctica, de realizar tareas de poder." ${ }^{121}$ Aclarando que, “(...) Los comandos surgirán con o sin acuerdo del Congreso, y van a ser poder popular en la medida en que se fortalezcan resolviendo problemas concretos y movilizando a la población para ello (...)",122

El último momento de este debate y de las experiencias que los dinamizan, se genera como respuesta al intento golpista del 29 de Junio en un claro intento por responder a la inminencia del golpe. Desde Julio en adelante comenzarán a masificársela emergencia de Cordones Industriales y Comandos Comunales. ${ }^{123}$ En este momento la formación del espacio público subalterno expresa un punto de avanzada, por la cantidad de cartas de opinión, foros y actividades llevadas adelante para esclarecer la línea política a seguir. Al mismo tiempo que posibilitó que las reflexiones de las clases subalternas aumentara en consistencia.

Un elemento elocuente al respecto lo constituye la opinión de un trabajador de la Corporación de Obras Urbanas del Ministerio de la Vivienda, quien señala

Cuando hablamos de participación, hablamos de poder, y éste va a estar en manos de quienes deciden: los trabajadores. Hemos superado las normas básicas sobre participación establecidas en el convenio CUTGobierno. Existen Comités de Obras y Comités de Producción, cada uno compuesto por cinco personas. Los integrantes del Comité de Producción más el jefe de obra se encargan de controlar el avance del trabajo. Cuando un problema transciende a los comités, se llama a la asamblea y allí se debate y discute. Esta que es una verdadera forma de poder popular se da en todas las obras, para fijar políticas ${ }^{124}$

Por su parte, Galvarino Escorza (PC), presidente del Sindicato Único Textil Progreso, preguntado sobre poder popular, Gobierno y CUT señala que:

Yo pienso que se debe y tenemos que crear poder popular con las masas, pero no desvinculado del Gobierno. Tiene que estar muy vinculado al Gobierno para que pueda ser un verdadero poder popular"

¿Eso significa que el poder popular tiene que ser dependiente del gobierno?

\footnotetext{
${ }^{121}$ Chile Hoy 52, Año II, semana del 8 al 14 junio de 1973, p. 9.

122 Ibídem.

${ }^{123}$ Eduardo Santa Cruz, "Comandos Comunales: órganos de poder del pueblo”, Documentos. Suplemento de la edición no. 189 de Punto Final, martes 31 de julio de 1973, 16 pp.

${ }^{124}$ Chile Hoy, no. 62, Año II, Semana del 17 al 23 de agosto de 1973. P. 15.
} 
NO, No. Tiene que estar vinculado, pero no depender de él. (...)

¿Cuál debe ser la relación cordones-CUT?

Pienso que tiene que ser muy estrecha: deben ser dirigidos por la CUT orientadas también por la Cetral. Pero eso sí: tendrán que darse en algunas oportunidades su propia organización, en eso estamos de acuerdo. Claro que es verdad que la propia Central necesita una reestructuración, porque está quedando un poco caduca $(\ldots)^{125}$

Finalmente, la discusión generada en el Foro Sobre Poder Popular organizado por la Revista Chile Hoy, entre partidos y representantes de las organizaciones de poder popular constituye un aporte significativo en relación al poder popular, la dualidad de poderes y su relación con el gobierno. ${ }^{126}$

Así para el MIR el poder popular era comprendido como un poder autónomo de la clase trabajadora, independiente del gobierno y autónomo del Estado, bajo una perspectiva de dualidad de poderes. Por su parte el MAPU-OC concibe no como un organismo paralelo, en la medida que el ejecutivo impulsa tareas concretas hacia la destrucción del estado burgués. En ese sentido, es concebido como un apoyo a las tareas de gobierno. Para el PS, la discusión se enmarca en un planteamiento mayor sobre el problema del poder, las características del Estado y la articulación bajo la vanguardia política. Finalmente el MAPU, identifica que el PP tiene dos filos, uno que es el gobierno que está dentro del estado burgués, intentando romperlo; y otro que son las masas, que empujan para romperlo. Finalmente el PS, señala el lugar que le corresponde al PP en la dualidad de poderes y en el marco de una estrategia de ruptura

Como se puede observar en el debate sumariamente revisado, los principales partidos fueron coincidentes en la identificación de las potencialidades del fenómeno de poder popular, estuvieron receptivos a la experiencia de movilización social y a la identificación del gobierno como una palanca de la lucha social. Las divergencias se establecieron más bien en las conceptualizaciones estratégicas y en el lugar le correspondía en ese plano a las instituciones del gobierno en relación al movimiento de masas.

A otro recuento, corresponde la identificación de las políticas específicas de cada partidos o de los fenómenos de constitución de lo Franck Gaudichaud ha denominado como "cordones en si" y "cordones para sí". Una historia que en el limbo del apostar por una ruptura democrática o establecer una solución negociada generó un tránsito que entregó el protagonismo a la sedición, al golpismo y a su objetivo deliberado por acabar de raíz con el problema arrastrando al país: "no a una guerra civil que ya está en pleno desarrollo, sino a la masacre fría, planificada de la clase obrera más consciente y organizada de Latinoamérica". ${ }^{127}$

\footnotetext{
125 Chile Hoy, no. 61, Año II, Semana del 10 al 16 de agosto de 1973, p. 9.

${ }^{126}$ Marta Harnecker, Jorge Modinger y Faride Zerán, "Foro sobre poder popular”, Chile Hoy, año 2, no. 60, del 3 al 9 de agosto de 1973.

${ }^{127}$ Carta de los cordones industriales a Salvador allende, 5 de septiembre de 1973.
} 


\section{Observaciones finales}

El debate sumariamente revisado nos permite afirmar la pertinencia de atender a las prácticas discursivas de poder para comprender el proceso de crisis de la dirección política del bloque socialista, como del sistema de partidos en una perspectiva de articulación ampliada. El trasfondo de esta manera de abordar el problema de las crisis de las instituciones del Estado de Compromiso, es que nos permite tomar en consideración las transformaciones de las dinámicas internas desde un enfoque que toma como centro las prácticas sociales, evitando así caer en generalizaciones que nos llevarían a generar un juicio normativo sobre la experiencia de politización a partir de consideraciones formales.

La importancia del proceso de politización de las clases subalternas y los debates teórico-ideológicos sostenidos en el espacio público subalterno a es que nos permiten comprender la relación orgánica existente entre partidos y movimientos sociales, específicamente en la discusión sobre el poder popular en relación al cambio de las coyunturas políticas.

Estas variaciones de la elaboración teórica estratégica del conjunto de los partidos, intelectuales y dirigentes sociales puso en evidencia las vacíos estratégicos en relación al curso estratégico de la vía chilena al socialismo, donde la mención al poder popular quedó comprendida como el desarrollo de la organización y politización en la base de las organizaciones sociales a partir de la cual implementar los principales puntos del programa de Gobierno. Al colocar en evidencia este vacío el conjunto de organizaciones políticas, sociales e intelectuales llevaron adelante un proceso de elaboración estratégica conjunta que tomó como significante de la politización la noción de poder popular, efectuado en un esapcio público subalterno.

Entendemos el espacio público subalterno como el lugar en el que el conjunto de actores del campo político se posicionaron en relación al conjunto de actores y tomaron posición en relacióna al proceso de radicalización política. Eta radicalización política vista a través de la noción de poder popular evidencia un proceso de elaboración colectivo en el que el conjunto de actores que formaron la izquierda del momento disputaron el sgnificante del poder popular.

En ese contexto de disputa del significante del poder popular evidenciamos una tensión entre intelectuales, dirigentes políticos y dirigentes sociales que conformaron el conjunto de la experiencia de elanboración colectiva. Así, de momentos se evidencia el rol jugado por los intelectuales como decodificadores de la experiencia de poder de las clases subalternas. Situación que evidenciamos en las intervenciones de Marta Harnecker, Thotonio Dos Santos, Pío García y Ruy Mauro Marini. El rol que se asignaron estos intelectuales desde las páginas de la Revista Chile hoy fue el de esclarecer las diferencias entre poder popular, la dualidad de poder y las consecución de la revolución.

Por su parte a los dirigentes políticos les correspondió el rol de dirección y orientación de la acción, en torno a este debate. Esto lo evidenciamos con fuerza en las intervencioes de Oscar Guillermo Garretón, Miguel Enríquez, Salvador Allende y Luis Corvalán, quienes sancionaban que experiencias correspondían a expresiones de poder 
popular y qué sentido tenían. Es decir, operaron como articuladores entre las experiencias de poder de las clases subalternas y el campo político. Esta lectura se efectuó en el caso de Miguel Enríquez, algunos dirigentes del PS y de Luis Corvalán desde un cuerpo teórico estrecho, cuya lectura del proceso revolucionario se agotaba en la transición socialista desde una perspectiva de la dualidad de poderes. Por el contrario, en las intervenciones de Oscar Guillermo Garretón y algunos dirigentes de la Izquierda Cristianas, quienes evaluaban el curso estratpegico a partir de las variaciones que se iban presentando en las coyunturas.

Sin embargo, a medida que el proceso se radicalizó, sobre todo desde el paro de Octubre, las organizaciones de las clases subalternas, expresadas en los cordones industriales y los comandos comunales comenzaron a romper la función de dirección y mediación de los dirigentes políticos. Esto lo evidenciamos en primer lugar, por el origen de estas organizaciones y por la manera en que comenzaron a intervenir en el debate a través de cartas, periódicos, foros y reportajes. Esta tensión posibilitó que el espectro se readecuara y los dirigentes políticos readecuaran su posicionamiento en relación al poder popular, que observamos con fuerza en el caso del PC.

En consideración a aquello lo que podemos desprender del debate revisado sobre el poder popular es que la elaboración estratégica estuvo rodeada de amplios espacios de ambigüedad, que se arrastran del marco socioeconómico en el cual se genera la convergencia de los partidos de la UP. El programa de la Unidad Popular constituyó un punto de consenso sobre un diagnóstico de las fallas del desarrollo socioeconómico que da cuenta del agotamiento de la estrategia de modernización adoptada desde finales de la década de 1930. Sin embargo, los vacíos en relación al sujeto político de las transformaciones tuvieron el problema de no poder situar de manera articulada teóricamente las expresiones y espacios de poder. Esto se agudizó a medida que las prácticas de movilización aumentaron y se profundizó desde el momento en que nuevos espacios de articulación fueron generando una subjetivación política que dificultó la generación de una dirección colectiva integrada.

Esta tensión no resuelta expresa la dificultad política de otorgarle un lugar estratégico a las expresiones sociales generadas por las clases subalternas y la dificultad de no haber pensado una articulación política que diera cuenta de los espacios de copamiento burocrático, relacionados al protagonismo desarrollado en la movilización por el movimiento popular y que desde 1970 fue conceptualizado como poder popular. 
Pablo Seguel, Prácticas de poder de las clases subalternas en el desarrollo del poder popular en Chile, 1967-1973 Political subjectivization practices in the development of the popular power in Chile, 1967-1973, Revista Izquierdas, 27, abril 2016, ISSN 0718-5049, pp. 161 - 199

\section{Bibliografía}

Documentos primarios

1. CEREN.

2. Chile Hoy.

3. El Siglo.

4. Posición.

5. Principios.

6. Punto Final.

7. Tarea Urgente.

Documentos Secundarios

1. Bize, Cristóbal. "Historia y memoria. Hacia una experiencia de poder popular: los trabajadores de la madera en la cordillera de Valdivia. (Neltume, 1970-1971). Memorias, historia y Derechos Humanos. Santiago: Universidad de Chile, 2012, pp.15-36.

2. Bourdie, Pierre. Razones prácticas, Barcelona, Anagrama, 1994

3. Casals, Marcelo, El alba de una revolución. La izquierda y el proceso de construcción estratégica de la "vía chilena al socialismo". 1956-1970, Santiago: LOM, 2011.

4. Castillo, Sandra, Cordones Industriales. Nuevas Formas de Sociabilidad Obrera y Organización Política Popular (Chile, 1970.1973), Concepción: Escaparate Ediciones, 2010.

5. Castro-Gómez, Santiago. Historia de la gubernamentalidad, Bogotá, Siglo del Hombre Editores, 2010.

6. Corvalán, Luis, Los partidos políticos y el golpe del 11 de septiembre. Contribución al estudio del contexto histórico, Santiago: Ediciones Universidad Bolivariana.

7. Echeverría, Olga y Lionetti, Lucía "La Historia Política en su complejidad: los aportes de la historia cultural y la historia intelectual", ponencia presentada a la V Jornadas Nacionales de Historia Moderna y Contemporánea.

8. Flisbish, Ángel, La política como compromiso democrático, Santiago, FLACSO, 1987.

9. Foucault, Michel. El nacimiento de la biopolítica. Buenos Aires, Fondo de Cultura Económica, 2012.

10. Foucault, Michel. Seguridad, territorio, población. Buenos Aires, Fondo de Cultura Económico, 2011.

11. Foxley, Alejandro, Para una democracia estable: economía y política, Aconcagua: CIEPLAN, 1985.

12. Garcés, Mario, "Lo político y lo social", en Revista Punto Final, no. 599, 2 de septiembre del 2005. Milos, Pedro y Garcés, Mario. Cuadernos de historia popular: serie Historia del movimiento obrero, Santiago, CETRAL/CEAL, no1, 1983.

13. Garretón, Manuel Antonio, El proceso político chileno, Santiago: FLACSO,

14. Gaudichaud, Franck, "El gobierno de Salvador Allende y su lucha por el "poder popular" (1970-1973), Poder Popular y Cordones Industriales, Santiago: LOM, 2006, pp. 13-54.

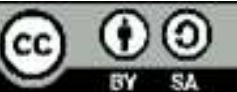


Pablo Seguel, Prácticas de poder de las clases subalternas en el desarrollo del poder popular en Chile, 1967-1973 Political subjectivization practices in the development of the popular power in Chile, 1967-1973, Revista Izquierdas, 27, abril 2016, ISSN 0718-5049, pp. 161 - 199

15. Gómez Leyton, Francisco, "El Estado capitalista de Compromiso. Difícil Camino al socialismo" [sin referencia], 1985.

16. Gómez Leyton, Juan Carlos, "Democracia versus propiedad privada. Los orígenes políticojurídicos de la dictadura militar chilena", Caetaneo, Gerardo (comp.), Sujetos sociales y nuevas formas de protesta en la historia recuente de América Latina, Buenos Aires: CLACSO, 2006, pp. 171-212.

17. Góngora, Mario. Ensayo histórico sobre la noción de Estado en Chile en los siglos XIX y $X X$, Santiago, Editorial Universitaria, 1998,

18. Henríquez, Renzo, El Poder del Campo. Los campesinos de Maipú durante el gobierno de Allende, Santiago, Londres 38, 2014.

19. Henríquez, Renzo, Industria Perlak "Dirigida y Controlada por los Trabajadores". Desalienación obrera en los tiempos de la Unidad Popular, 1970-1973", Revista www.izquierdas.cl, Santiago, número 20, septiembre 2014.

20. Henríquez, Renzo, El Poder del Campo. Los campesinos de Maipú durante el gobierno de Allende, Santiago: Londres 38, espacio de memorias, 2014.

21. Jara, Isabel. La crisis del sistema democrático: las elecciones presidenciales y los proyectos políticos exlcuyentes. Chile, 1958-1970. Santiago, Editorial Universitaria, 2014, p. 34.

22. Marín, Juan Carlos, El ocaso de una ilusión.1967-1973, Buenos Aires: Picaso/INEDH/Colectivo Ediciones, 2007.

23. Marini, Ruy Mauro, ¿Transición o Revolución?, mimeo, 1973.

24. Marini, Ruy Mauro, Dos estrategias en el proceso chileno, mimeo, 1974.

25. Marini, Ruy Mauro, Economía Política de un golpe militar, mimeo, 1974.

26. Marini, Ruy Mauro, La pequeña burguesía y el problema del poder, mimeo, 1976.

27. Marini, Ruy Mauro. Subdesenvolvimento e revolução. Florianópolis: Editora Insular, 2013.

28. Mariniu, Ruy Mauro, Antecedentes para el estudio del movimiento de masas en el periodo, mimeo, 1976.

29. Martínez, Javier y Tironi, Eugenio, Las clases sociales en Chile, Santiago: SUR, 1985

30. Mascareño, Aldo, "Acción y estructura en américa Latina. De la matriz sociopolítica a la diferenciación funcional", En: Persona y sociedad, Santiago: Universidad Alberto Hurtado, vol. XXIII, no. 2, 2009, pp. 65-89.

31. Mazzeo, Miguel, Introducción al poder popular. El sueño de una cosa, Santiago, Tiempo Robado Editoras, 2014.

32. Modonosi, Massimo. Subalternidad, antagonismo, autonomía. Marxismo y subjetivación política. Buenos Aires: CLACSO, 2010.

33. Monsálvez, Danni. "La Asamblea del Pueblo en Concepción. La Expresión del poder popular". Revista de Historia, Número 2, $2^{\circ}$ semestre, Volumen 16, año 2006. Publicación del Departamento de Ciencias Históricas y Sociales. Universidad de Concepción.

34. Moulian, Tomás, "La vía chilena al socialismo: itinerario de la crisis de los discursos estratégicos de la Unidad Popular", en: Pinto, Julio (coor.), Cuando hicimos Historia. La experiencia de la Unidad Popular, Santiago: LOM ediciones, 2005.

35. Moulian, Tomas, Contradicciones del desarrollo político chileno, Santiago: LOM, 2010.

36. Moulian, Tomás, Democracia y Socialismo, Chile, Santiago: FLACSO, 1983.

37. Moulian, Tomás, Fracturas. De Pedro Aguirre Cerda a Salvador Allende (1938-1973), Santiago: LOM, 2006.

38. Pinto, Aníbal. Chile, un caso de desarrollo frustrado, Santiago, Editorial Universitaria, 1962. 
Pablo Seguel, Prácticas de poder de las clases subalternas en el desarrollo del poder popular en Chile, 1967-1973 Political subjectivization practices in the development of the popular power in Chile, 1967-1973, Revista Izquierdas, 27, abril 2016, ISSN 0718-5049, pp. 161 - 199

39. Ramos, Sergio, ¿Chile, una economía en transición?, La Habana: Casa las Américas, 1972.

40. Salazar, Gabriel, La violencia política popular en las grandes alamedas, Santiago: LOM, 2006.

41. Salazar, Gabriel, Movimientos sociales en Chile. Trayectoria histórica y proyección política, Santiago, Chile: Uqbar editores, 2006.

42. Seguel, Bryan y Urrutia, Miguel, "Prácticas de poder popular y ruptura democrática. Chile, 1965-2014”, En: Mazzeo, Miguel, Introducción al poder popular, Santiago, Tiempo Robado Editoras, 2014.

43. Seguel, Bryan [Pablo], "La discusión política del Poder Popular en la crisis del Estado Capitalista de Compromiso de Clases. Chile, 1967-1973”, en: Construcción y Recuperación de la Memoria Histórica. Reflexiones a 40 años del Golpe Militar”, Santiago, Universidad de Chile, pp. 77-94

44. Silva, Miguel, Los Cordones Industriales y el Socialismo desde Abajo, Santiago, autoedición, 2013.

45. Sunkel, Osvaldo, El presente como historia, Santiago: Catalonia, 2011.

46. Urrutia, Miguel y Londres 38, Los retornos del poder popular: el MIR y el cordón cerrillos Maipú. 1972-1973, mimeo.

47. Urrutia, Miguel y Seguel, Pablo. "El aporte de las ciencias humanas a las pervivencias del golpe de Estado. Cuarenta y más años para una ruptura democrática en Chile". Sociedad Hoy 25, Concepción, $2^{\circ}$ sem. 2013, pp. 97-143

48. Urrutia, Miguel, Prácticas de politización y poder popular en Chile, Londre 38, mimeo, 2012.

49. Valenzuela, Arturo, El quiebre de la democracia en Chile, Santiago: FLACSO, 1978.

50. Valenzuela, Iván. "Modernidad, Teoría Social y Organización: reflexiones sobre antiguos desencuentros y nuevos encuentros", Revista Ciencias Sociales, 12, 2002 pp. 93-107.

51. Varios Autores, El ladrillo: bases de la política económica del gobierno militar chileno, Santiago: Centro de Estudios Públicos, 1992.

52. Veyne, Paul. Cómo se escribe la historia. Madrid, Alianza Editorial, 1984.

53. Weffort, Francisco, "El populismo en la política brasileña". En: Brasil Hoy, México D.F:Siglo XXI, 1968.

54. Weffort, Francisco, "Estado y masas en el Brasil", Pensamiento Crítico, Habana, n ${ }^{\circ}$ 5, junio de 1967.

55. Winn, Peter, Los tejedores de la revolución, Santiago: LOM, 2004 www.redalyc.org/pdf/902/90239866007.pdf

56. Zemelman, Hugo, "El movimiento popular chileno y el sistema de alianzas en la década de 1930”, En: Faletto, Enzo, Ruiz, Hugo y Zemelman, Hugo, Génesis histórica del proceso político chileno, Santiago: Quimantú, 1972. pp. 33-116. 